TECTONICS, VOL. 11, NO. 3, PAGES 586-602, JUNE 1992

\section{TECTONIC HISTORY OF THE EASTERN EDGE OF THE ALEXANDER TERRANE, SOUTHEAST ALASKA}

Charles M. Rubin ${ }^{1}$ and Jason B. Saleeby

Division of Geological and Planetary Sciences, California Institute of Technology, Pasadena

Abstract. Rocks exposed west of the Coast Plutonic Complex in southern southeast Alaska form an imbricate thrust belt that overprints the tectonic boundary between two of the largest allochthonous crustal fragments in the North American Cordillera, the Insular and Intermontane composite terranes. In the Alexander terrane (Insular composite terrane), lower Paleozoic metavolcanic and metasedimentary rocks (Descon Formation) and dioritic plutons are unconformably overlain by Lower Devonian clastic strata (Karheen Formation). These rocks are overlain locally by Upper Triassic basalt, rhyolite and marine clastic strata (Hyd Group). Upper Jurassic and Lower Cretaceous metavolcanic and metasedimentary strata of the Gravina sequence unconformably overlie the Alexander terrane. The Gravina sequence forms a structural package over $15 \mathrm{~km}$ thick and records intermittent arc volcanism along the eastern edge of the Alexander terrane. The Gravina sequence is structurally overlain by upper Paleozoic and lower Mesozoic metamorphosed basaltic strata, marble, and argillite (Alava sequence), and locally by lower Paleozoic supracrustal rocks and orthogneiss (Kah Shakes sequence). Together, these constitute the Taku terrane which we correlate with the Intermontane composite terrane. Local unconformity of Gravina sequence strata over the Alava sequence demonstrates that the Gravina sequence overlapped an earlier structural boundary between the Intermontane and Insular composite terranes. The rocks were deformed in the mid-Cretaceous by west-vergent thrusting that was was broadly coeval with arc magmatism. Deformation involved emplacement of westdirected thrust nappes over the structurally intact and relatively unmetamorphosed Alexander terrane basement. MidCretaceous tonalite, granodiorite, and quartz diorite intrude rocks of the thrust belt and are locally affected by the deformation. Mid-Cretaceous deformation occurred during two episodes that were contemporaneous with the emplacement of large sill-like plutons. Older structures record ductile southwest-vergent folding and faulting, regional metamorphism, and development of axial-planar foliation. The second-generation structures developed during the later stages of southwest-directed thrust faulting, which juxtaposed rocks of contrasting metamorphic pressures and temperatures. Structural, stratigraphic, and geochronologic data indicate that the two phases of regional thrusting in southeast Alaska occurred between $113 \mathrm{Ma}$ and $89 \mathrm{Ma}$. Rocks in the western part of the thrust belt were uplifted regionally by $70 \mathrm{Ma}$. Deformation involved the collapse of a marginal basin(s) and a magmatic arc, and overprinted the older tectonic boundary between the Insular composite terrane and the late Mesozoic western margin of North America (at that time the

\footnotetext{
$\mathbf{1}_{\text {Now at Department of Geology, Central Washington }}$ University, Ellensburg.
}

Copyright 1992 by the American Geophysical Union.

Paper number 91TC02182

0278-7407/92/91TC-02182\$10.00
Intermontane composite terrane). Contractional deformation along the length of the thrust belt was broadly coeval with arc magmatism, and thus records intra-arc tectonism. Late Paleocene to early Eocene igneous activity and extensional (?) deformation subsequently affected the thrust belt.

\section{INTRODUCTION}

Structurally imbricated metamorphic rocks are intermittently exposed along the western flank of the Coast Plutonic Complex and extend for approximately $2000 \mathrm{~km}$ along strike, from northern Washington to southeast Alaska (Figure 1). Detailed structural, stratigraphic, and geochronologic data from the metamorphic rocks are critical for understanding the accretionary history of the northwestern Cordillera. The metamorphic rocks contain mantle-derived, juvenile crustal material represented by the Alexander terrane on the west and fringing continental volcanic arc rocks and continentally derived slope-and-rise deposits of the North American continent on the east. One of the outstanding tectonic problems in the northwestern Cordillera is the nature of the boundary between allochthonous ensimatic crustal fragments, consisting of the Alexander and Wrangellia terranes (Insular composite terrane of Wheeler and McFeely [1987]), and the western margin of late Mesozoic North America (Intermontane composite terrane of Wheeler and McFeely [1987]). The Ketchikan area provides a strategic link across this boundary because it is relatively unaffected by Tertiary plutonism. Distinctive stratigraphic sequences record the late Mesozoic continent-margin history of western North America. Recent work [Crawford et al., 1987; Rubin et al., 1990a] shows that regionally metamorphosed rocks form a late Mesozoic fold and thrust belt and involve both crystalline basement and its volcanic and basinal cover. Mid-Cretaceous thrust belt deformation is well documented and was broadly coeval with arc magmatism, involving the emplacement of west-directed thrust nappes over a structurally intact and relatively unmetamorphosed basement. The presence of inverted metamorphic isograds beneath thrust faults indicates that hot metamorphic and plutonic rocks were translated over a relatively cold basement.

In this paper, we describe the general stratigraphy and broad structural geometry of metamorphic rocks from the Ketchikan area that include the Alexander and Taku terranes and Gravina sequence. U-Pb zircon geochronologic data and a relative structural chronology allow us to establish the timing of deformation in relation to isotopically dated plutons. Furthermore, by establishing the structural setting of syntectonic and posttectonic plutons and with the use of zircon geochronology, we are able to establish the absolute timing and tectonic setting of thrust belt evolution. Stratigraphic correlations, regional structure, and $\mathrm{U}-\mathrm{Pb}$ zircon geochronology, discussed in detail by Rubin and Saleeby $[1991 \mathrm{a}, \mathrm{b}, \mathrm{c}]$, are summarized below. The data presented in this paper are based upon detailed geologic field mapping along the shorelines and ridges of Cleveland Peninsula, Revillagigedo, Annette, Gravina, and smaller adjacent islands (Figure 2).

\section{GEOLOGIC SETTING}

The Alexander terrane forms structural basement for most of the rocks that lie west of the Coast Plutonic Complex. The Alexander terrane consists of a structurally intact lower Paleozoic ensimatic arc sequence overlain by middle Paleozoic clastic and carbonate strata that are unconformably capped by 


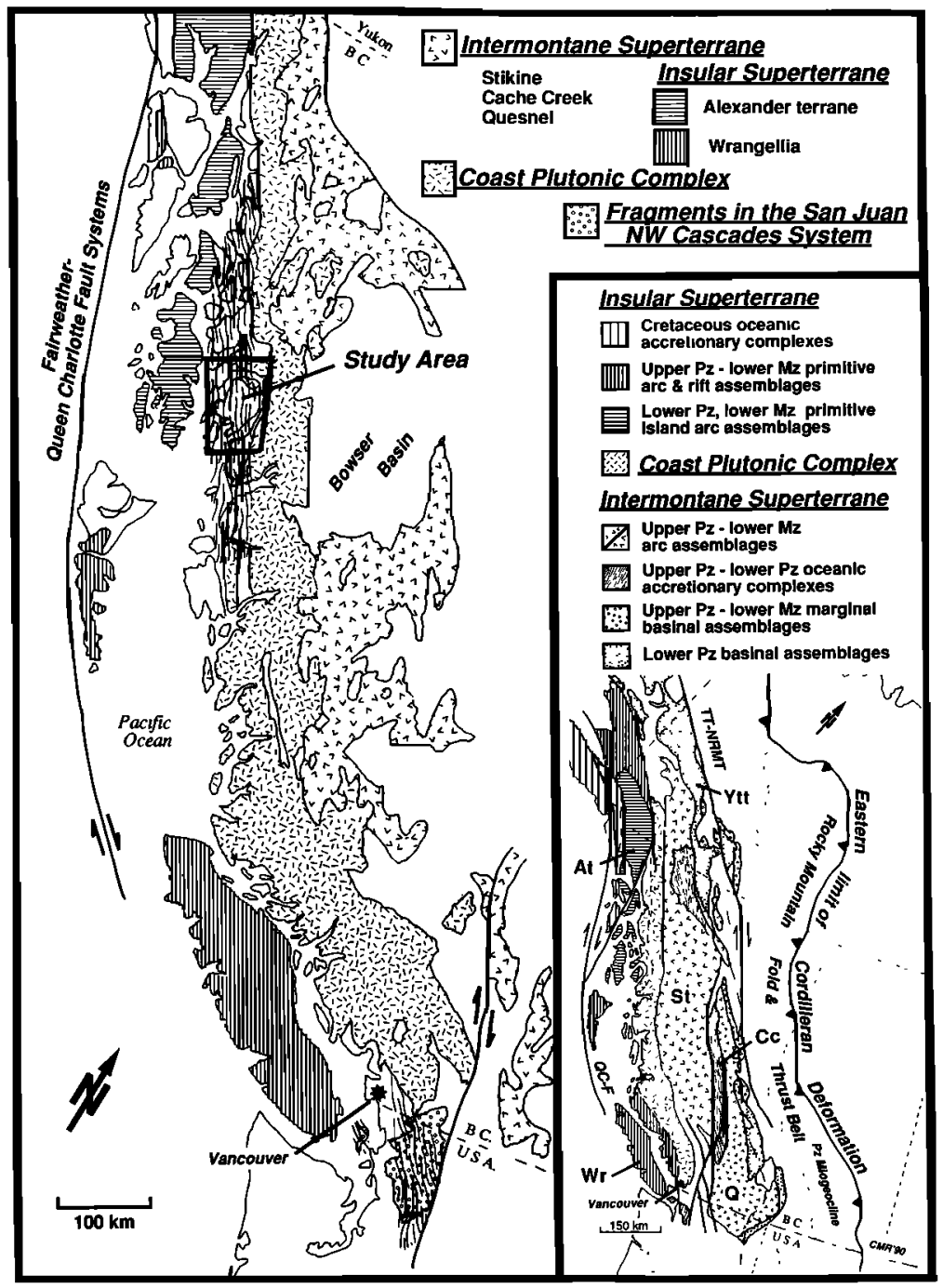

Fig. 1. Generalized geologic map of the northwestern Cordillera with study area indicated. Areas of midCretaceous and younger deformation are stippled. Terrane map of the Canadian Cordillera is shown in inset. $\mathrm{Pz}$ is Paleozoic; $\mathrm{Mz}$ is Mesozoic.

an Upper Triassic rift assemblage [Gehrels and Saleeby, 1987]. In most areas, rocks of the Alexander terrane are only slightly deformed and are not highly metamorphosed, except near the eastern boundary where they are overprinted by late Mesozoic deformational structures. Upper Jurassic to Lower Cretaceous marine pyroclastic and basinal strata of the Gravina sequence depositionally overlie the Alexander terrane. The middle Paleozoic and lower Mesozoic Alava sequence and lower to mid-Paleozoic Kah Shakes sequence (part of the Taku terrane of Berg et al. [1988]) structurally overlic the Alexander terrane and Gravina sequence. Locally, channel-fill deposits of the Gravina sequence overlie the Alava sequence and thus form an overlap between the Alexander terrane and the Alava sequence [Rubin and Saleeby, 1991a). The Kah Shakes sequence locally occupies higher structural levels on northeast Cleveland Peninsula, western Revillagigedo Island and northwestern Portland Peninsula (Figure 2) and consists of lower Paleozoic meta-silicic tuff, quartzite, marble, metabasalt, calc-silicate, and orthogneiss.

A regionally extensive mid-Cretaccous west-vergent thrust belt containing imbricated Gravina, Alava, and Kah Shakes sequences occurs along parts of the eastem boundary of the Alexander terrane (Figure 3). The thrust belt consists of an imbricate series of west-vergent thrust sheets; on Cleveland Peninsula the imbricated package has a total structural thickness of over $15 \mathrm{~km}$. On the basis of field relations and geochronology discussed here, the thrust belt was active over a relatively short period of time and was broadly coeval with arc magmatism.

\section{GEOLOGIC FRAMEWORK}

\section{Alexander Terrane}

Lower Paleozoic metavolcanic rocks. The southern part of Cleveland Peninsula and part of the western side of Revillagigedo Island are underlain by metavolcanic rocks, with subordinate phyllite and marble of Ordovician to Early Silurian (?) age (Figure 2). The lower contact of this mafic 


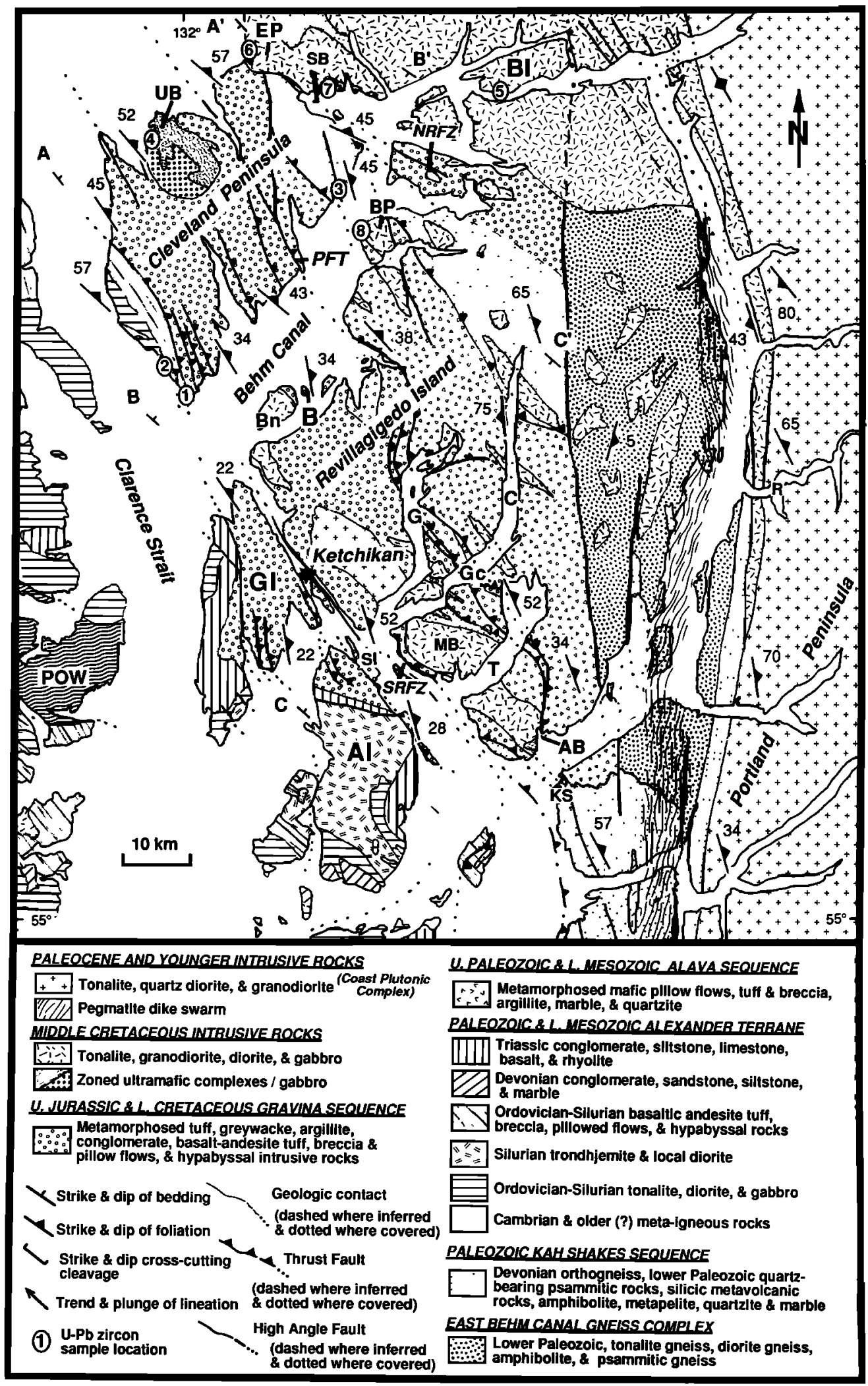




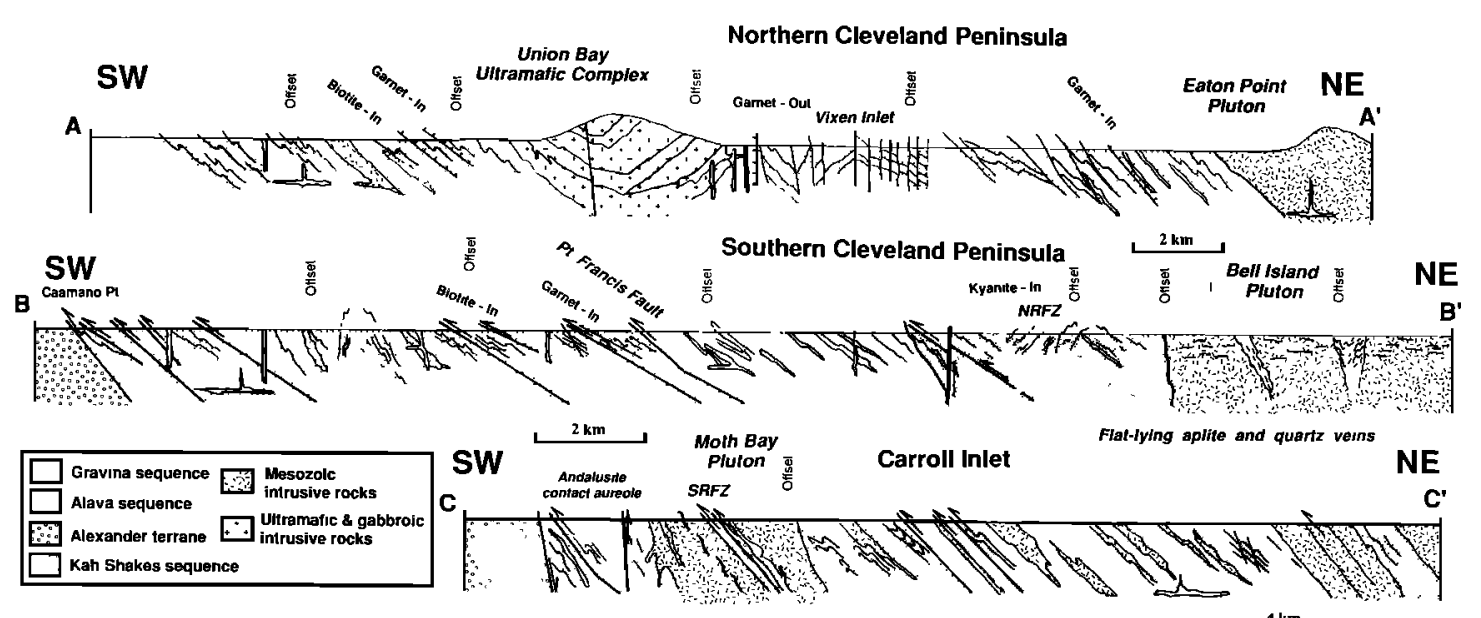

Fig. 3. Geologic cross sections: A-A', northern Cleveland Peninsula; B-B', southem Cleveland Peninsula; C-C', Carroll Inlet. Locations of cross sections shown in Figure 2. No vertical exaggeration.

sequence is not exposed. The upper contact is faulted against the Upper Jurassic to Lower Cretaceous Gravina sequence and is depositionally overlain by the Devonian Karheen Formation on western Cleveland Peninsula. The minimum age of metavolcanic rocks on the southwestern part of Cleveland Peninsula is constrained by a cross cutting trondhjemite dike, with single-fraction U-Pb zircon age of $443 \pm 4 \mathrm{Ma}$ (sample 1 , Tables 1 and 2). Although there was insufficient material to obtain multiple analyses, the internally concordant Late Ordovician age is similar to ages of metaigneous rocks of the Descon Formation on Prince of Wales Island [Saleeby et al., 1984]. Similar metavolcanic and metasedimentary rocks on central and southern Prince of Wales Island range in age from Early Ordovician to Early Silurian and are assigned to the Descon Formation [Eberlein et al., 1983; Herreid et al., 1978; Gehrels and Saleeby, 1987; Gehrels et al., 1987]. On the basis of similar rock types, stratigraphic position, and age, we assign the mafic metavolcanic and metasedimentary strata on southwestern Cleveland Peninsula to the Descon Formation. There is a possibility that the metavolcanic rocks on southem Cleveland Peninsula represent slightly deformed Wales Group, inasmuch as the Wales Group lies regionally beneath the Descon Formation; however, such an interpretation does not fundamentally affect our analysis.

On Cleveland Peninsula, the Descon Formation consists of lower greenschist facies metabasalt flows, breccia, and tuff. The mafic metavolcanic strata contain euhedral augite and feldspar phenocrysts in a pale to dark green tuffaceous matrix comprised of albite, chlorite, epidote, and white mica. The mafic metavolcanic strata are locally interlayered with marble and argillite; marble beds range in thickness between 1 and 3 m. The Descon Formation in this region contains a greater proportion of mafic metavolcanic rocks than are present in correlative strata on Prince of Wales Island. No fossils have been recovered from these lower Paleozoic rocks on Cleveland Peninsula.

Metaplutonic Complex. Metamorphosed gabbro, diorite, and plagioclase and quartz porphyritic granodiorite underlie much of southwestern Cleveland Peninsula (Figure 2). Plagioclase and quartz porphyritic granodiorite occurs as homogeneous, massive to foliated bodies containing oligoclase, quartz, interstitial microperthite, and minor hornblende. Heterogenous bodies of foliated and layered diorite, quartz diorite, and gabbro consist of texturally varied, fine- to medium-grained plagioclase, hornblende, biotite, and minor quartz. The widespread foliation is defined by micas and mafic phases. Minor homblendite and clinopyroxenite sills and dikes display complex intrusive relations with the diorite and granodiorite. Interlayered foliated dikes and sills of diorite and gabbro are cross cut by porphyritic intrusive bodies. The quartz porphyritic and diorite plutonic rocks intrude screens and septa of foliated augite-phyric metabasalt and marble that are part of the Descon Formation. All intrusive units are, in turn, crosscut by leucogabbro and diorite pods and sills and by quartz and feldspar veins. Zircon from a foliated metadiorite dike yields a U-Pb age of $445 \pm 8 \mathrm{Ma}$ (sample 2, Tables 1 and 2). The metaplutonic rocks exposed on Cleveland Peninsula are similar in composition, texture, lithology, and intrusive relations to metaplutonic rocks exposed to the west across Clarence Strait on Kaasan Peninsula [Eberlein et al., 1983]. On the basis of these geologic relations and the continuity of exposure along the southwestern side of Cleveland Peninsula and the east side of Kaasan Peninsula, the metaplutonic rocks on Cleveland Peninsula are interpreted to be correlative with similar rocks on Kaasan Peninsula.

$U-P b$ zircon geochronology. All zircon fractions from the

Fig. 2. Geologic map showing distribution of geologic units, major structures, and zircon sample locations on Cleveland Peninsula and Revillagigedo and adjacent islands. Abbreviations are AB, Alava Bay; B, Back Island; Bn, Betton Island; BI, Bell Island Pluton; BP, Bushy Point Pluton; C, Carol Inlet; EP, Eaton Point Pluton; Gc, Gnat Cove, G, George Inlet; MB, Moth Bay Pluton; POW, Prince of Wales Island; SB, Spacious Bay; SI, Spire Island; T, Thorne Arm; UB, Union Bay Ultramafic Complex. NRFZ is northern Revillagigedo Island fault zone; SRFZ is southem Revillagigedo Island fault zone. Adapted from Berg [1972, 1973] (parts of Annette and Gravina islands), Gehrels and Saleeby [1987] (Prince of Wales Island, parts of Annette, Duke, and Gravina islands), and this work (Cleveland Peninsula and Revillagigedo and adjacent islands). A-A', B-B', and C-C' indicate locations of cross sections in Figure 3. 
TABLE 1. U-Pb Geochronologic Sample Locations From the Ketchikan Area

\begin{tabular}{|c|c|c|c|c|}
\hline Sample & Latirude & Longitude & Field Setting & Zircon Properties \\
\hline 1 & $\mathrm{~N} 55^{\circ} 30^{\prime} 00^{\prime \prime}$ & $131^{\circ} 59^{\prime} 6^{\prime \prime}$ & $\begin{array}{l}\text { Nonfoliated, medium-grained } \\
\text { trondhjemite dike - intrudes } \\
\text { greenschist facies metavolcanic } \\
\text { rocks and marble }\end{array}$ & $\begin{array}{l}\text { 2:1; Sub=An>Eu; irregular shapes; colorless, } \\
\text { grey-tint; inclusions common }\end{array}$ \\
\hline 2 & N55'31"24" & $131^{\circ} 1^{\prime} 61^{\prime \prime}$ & $\begin{array}{l}\text { Slighlly altered and foliated } \\
\text { medium-grained quartz diorite, in } \\
\text { a heterogeneous sequence of } \\
\text { diorite, amphibolite, homblendite, } \\
\text { and pyroxenite }\end{array}$ & $\begin{array}{l}\text { 2:1; Sub>Eu>An; irregular shapes; colorless, } \\
\text { grey-to pink -int; inclusions common }\end{array}$ \\
\hline 3 & N55 $46^{\prime} 43^{\prime \prime}$ & $131^{\circ} 48^{\prime} 3^{\prime \prime}$ & $\begin{array}{l}\text { Highly foliated medium-grained } \\
\text { micaceous quartzite }\end{array}$ & $\begin{array}{l}\text { 1:1; An }>\text { Sub }>\text { Eu; rounded, irregular shapes; } \\
\text { grey- to red-tint; inclusions common in all } \\
\text { grains: Detrital zircon }\end{array}$ \\
\hline 4 & N55 $54^{\prime} 15^{\prime \prime}$ & $131^{\circ} 11^{\prime \prime \prime}$ & $\begin{array}{l}\text { Massive, very fine-grained } \\
\text { gabbroic pods and dikes that are } \\
\text { interstitial to homblendite } \\
\text { associated with the Union Bay } \\
\text { Ulramafic Complex }\end{array}$ & $\begin{array}{l}\text { 3:1;Eu>Sub>An; colorless, pink-lint inclusion } \\
\text { frec }\end{array}$ \\
\hline 5 & N55 $55^{\prime} 00^{\prime \prime}$ & $131^{\circ} 3320^{\prime \prime}$ & $\begin{array}{l}\text { Massive, slightly foliated, medum- } \\
\text { grained biotite tonalite, part of the } \\
\text { Bell Island Pluton }\end{array}$ & 2:1; Eu>Sub>An; pale pink-tint inclusion free \\
\hline 6 & N5559'57" & $132^{\circ} 35^{\prime \prime}$ & $\begin{array}{l}\text { Nonfoliated, medium-grained } \\
\text { biotite granodiorite, part of the } \\
\text { Eaton Point Pluton }\end{array}$ & $\begin{array}{l}\text { 3:1; Eu>Sub }>\text { An; colorless, pink-tint inclusion } \\
\text { free }\end{array}$ \\
\hline 7 & N55 $758^{\prime \prime}$ & $132^{\circ} 51^{\prime} 13^{\prime \prime}$ & $\begin{array}{l}\text { Nonfoliated, medum-grained } \\
\text { porphyritic granodionite, exposed } \\
\text { on the northem shore of Spacious } \\
\text { Bay, par t of the Eaton Point } \\
\text { Phiton }\end{array}$ & $\begin{array}{l}\text { 3:1; Eu>Sub>An; colorless, pink-tint unclusion } \\
\text { free }\end{array}$ \\
\hline 8 & $\mathrm{~N}^{\circ} 5^{\circ} 48^{\prime} 42^{\prime \prime}$ & $131^{\circ} 47^{\prime \prime \prime}$ & $\begin{array}{l}\text { Massive to slighly foliated, } \\
\text { medium- to coarse-grained } \\
\text { epidote-bearing granodionite, part } \\
\text { of the Bushy Point Pluton }\end{array}$ & $\begin{array}{l}\text { 3:1; Eu>Sub }>\text { An; colorless, very pale pink-tint, } \\
\text { inclusion free }\end{array}$ \\
\hline
\end{tabular}

Abbreviations are Eu, euhedral; Sub, subhedral; An, anhedral. 2:1, length.width ratios of zircon grains. Color determined under reflected light.

Paleozoic samples yield discordant U-Pb and $\mathrm{Pb}-\mathrm{Pb}$ data. Both samples (samples 1 and 2) have $\mathrm{Pb}-\mathrm{Pb}$ ages from 443 to 445 $\mathrm{Ma}$ and $\mathrm{U}-\mathrm{Pb}$ ages in the 330-430 Ma range (Table 2). Zircon in these samples lacks optically distinguished cores or compositional zoning. We interpret the discordance as the result of episodic lead loss during Mesozoic and Cenozoic time, due to a younger thermal disturbance. This interpretation is supported by hornblende and biotite $\mathrm{K}-\mathrm{Ar}$ ages, as young as $~ 79 \mathrm{Ma}$, from Paleozoic Alexander terrane rocks on Annette and Duke islands [Smith and Diggles, 1981]. Both polyphase deformation and mid-Cretaceous greenschist facies metamorphism have affected the Alexander terrane rocks and perhaps contributed to the isotopic disturbance. This interpretation is in accord with that of Gehrels and Saleeby [1987], who report similar disturbance of U-Pb isotopic systems in metaplutonic rocks of the Alexander terrane. Alternatively, the U-Pb isotopic disturbance may be due to later mid-Teritary hyrdothermal activity and associated fluid flow [Magaritz and Taylor, 1986].

Karheen Formation. Interbedded siliceous argillite and micaceous limestone overlain by distinctive pebble to cobble conglomerate layers, $30-50 \mathrm{~cm}$ thick, unconformably overlie metaplutonic rocks on the shoreline south of Niblack Hollow on western Cleveland Peninsula (Figure 2). Clasts in the conglomerate are matrix supported and are usually less than 5 $\mathrm{cm}$ in diameter in an argillaceous limestone matrix. Clasts consist of rounded to subangular plutonic and volcanic clasts, and vein quartz. Basaltic sills and dikes intrude the sequence. No fossils have been recovered from the clastic sequence. On the basis of similarities of stratigraphic position and lithology, the clastic strata are interpreted as part of the Lower Devonian conglomeratic part of the Karheen Formation, exposed on central Prince of Wales Island [Eberlein et al., 1983]. On Prince of Wales Island, similar strata consisting of pebble to cobble conglomerate, limestone, shale, and greywacke unconformably overlie metaplutonic diorite [Eberlein et al., 1983]. The conglomeratic strata record uplift and erosion of Ordovician and Silurian rocks during the Klakas orogeny [Gehrels et al., 1987].

Hyd Group. Upper Triassic strata of the Hyd Group on Annette and Gravina islands consist of limestone, fine- to coarse-grained clastic sedimentary rocks, and basalt to rhyolite volcanic rocks (Figure 2) [Berg, 1972, 1973]. These rocks unconformably overlie pre-Devonian strata of the Alexander terrane and are unconformably overlain by the Upper Jurassic to Lower Cretaceous Gravina sequence (see discussion below). These Upper Triassic strata recently described by Gehrels et al. [1987] are not present on Cleveland Peninsula and Revillagigedo Island.

\section{Taku Terrane}

Alava sequence. The Alava sequence (part of the the Taku terrane of Berg et al. [1988]) is a distinctive upper Paleozoic 
and lower Mesozoic stratified sequence and, along with the Gravina sequence, is exposed along the eastern boundary edge of the Alexander terrane along its $100-\mathrm{km}$ extent in the Ketchikan area. The sequence is fault bounded on the east by lower to middle Paleozoic orthogneiss, and locally on eastern Revillagigedo Island the sequence is intruded by Cretaceous and younger foliated tonalite and granodiorile.

The Alava sequence, in southern southeast Alaska, consists of two members: a lower member of Upper Pennsylvanian and Lower Permian metavolcanic and metasedimentary assemblage, and a upper member of Middle to Upper Triassic mixed metasedimentary and metavolcanic assemblage [Rubin and Saleeby, 1991a]. The lower member consists of massive crinoidal marble interlayered with black argillite and phyllite, and mafic metavolcanic flows, breccia, tuff, pillowed flows, and minor quartzite. The upper member comprises carbonaceous and siliceous nodular limestone, argillite, mafic metavolcanic tuff, breccia, and pillowed flows. The base of the Alava sequence is not exposed, and the sequence structurally overlies either the Gravina or Kah Shakes sequences or the Alexander terrane. Locally, strata of the Gravina sequence unconformably overlie the Alava sequence [Rubin and Saleeby, 1991b, c].

On the basis of lithology, broad age constraints, and tectonic setting, the Alava sequence might be correlative with the upper Paleozoic parts of the Yukon-Tanana terrane, whereas the lower Mesozoic portion of the Alava sequence is correlated with the Triassic portion of the Stikine terrane (e.g., Stuhini Group [Rubin and Saleeby, 1991a]).

Kah Shakes sequence. The Kah Shakes sequence (part of the Taku and Tracy Arm terranes of Berg et al. [1988] comprises metamorphic rocks exposed along the westem flank of the Coast Plutonic Complex and forms screens and septa within part of the Coast Plutonic Complex (Figures 1 and 2) [Salecby and Rubin, 1990a]. The sequence is bounded on the west by a thrust fault in which the Alexander terrane forms the lower plate, and is intruded on the east by the voluminous Cretaceous and Tertiary plutonic rocks of the Coast batholithic belt. On southernmost Revillagigedo Island, the Kah Shakes sequence structurally overlies the Alexander terrane along an east-dipping thrust fault. The sequence consists of a thick succession of quartzite and carbonate-rich turbidites, siliceous and quartzo-feldspathic schist, subordinate metabasalt, pelitic schist, and orthogneiss (Figure 4). Highly deformed micaceous quartzite from eastern Cleveland Peninsula yielded a very small, heterogeneous zircon population (sample 3, Table 1). Because of the very small sample size, one fraction (62-80 $\mu \mathrm{m}$ ) was analyzed for its "average" isotopic properties. A Precambrian ${ }^{207} \mathrm{~Pb}-{ }^{206} \mathrm{~Pb}$ average age of $2.03 \mathrm{Ga}$ for the quartzite is a minimum age for the oldest component in the fraction and indicates that Precambrian rocks formed part of the ultimate source for the quartz-rich detritus. To the south on Portland Peninsula, similar Precambrian ${ }^{207} \mathrm{~Pb}-206 \mathrm{~Pb}$ ages on Kah Shakes quartzite have been reported [Saleeby and

TABLE 2. U-Pb Zircon Isotopic Age Data for the Alexander Terrane, Kah Shakes Sequence and Mid-Cretaceous Plutons

\begin{tabular}{|c|c|c|c|c|c|c|c|c|c|c|c|}
\hline \multirow[b]{2}{*}{ Sample } & \multirow[b]{2}{*}{$\begin{array}{c}\text { Fraction, } \\
\mu \mathrm{m}\end{array}$} & \multirow[b]{2}{*}{$\begin{array}{c}\text { Amount } \\
\text { Analyzed, } \\
\text { mg }\end{array}$} & \multicolumn{2}{|c|}{ Concentrations, ppm } & \multicolumn{4}{|c|}{ Atomic Ratios } & \multicolumn{3}{|c|}{ Isotopic Ages, Ma } \\
\hline & & & ${ }^{238} \mathrm{U}$ & ${ }^{206} \mathrm{~Pb}^{*}$ & $\frac{{ }^{206} \mathrm{~Pb}}{{ }^{204} \mathrm{~Pb}}$ & $\frac{{ }^{206} \mathrm{~Pb}^{*}}{238 \mathrm{U}}$ & $\frac{{ }^{207} \mathrm{~Pb}^{*}}{235 \mathrm{U}}$ & $\frac{{ }^{207} \mathrm{~Pb}^{*}}{206 \mathrm{~Pb}^{*}}$ & $\frac{206 \mathrm{~Pb}^{*}}{238 \mathrm{U}}$ & $\frac{207 \mathrm{~Pb}^{*}}{235 \mathrm{U}}$ & $\frac{207 \mathrm{~Pb}^{*}}{206 \mathrm{~Pb}^{*}}$ \\
\hline \multicolumn{12}{|c|}{ Alexander terrane } \\
\hline 1 & $45-62$ & 0.6 & 130 & 7.9 & 7110 & $\begin{array}{l}\text { Trondh } \\
0.07289(44)\end{array}$ & $\begin{array}{c}\text { jemite Dik } \\
0.05403\end{array}$ & $0.05578(14)$ & 438.0 & 438.7 & $443 \pm 4$ \\
\hline $\begin{array}{l}2 \\
2 \\
2\end{array}$ & $\begin{array}{c}45-62 \\
62-80 \\
>80\end{array}$ & $\begin{array}{l}2.7 \\
2.3 \\
1.0\end{array}$ & $\begin{array}{r}1167 \\
991 \\
1201\end{array}$ & $\begin{array}{l}53.1 \\
49.2 \\
67.1\end{array}$ & $\begin{array}{r}42995 \\
50280 \\
5742\end{array}$ & $\begin{array}{r}\text { Foliated } \\
0.052550(36) \\
0.053064(34) \\
0.064319(54)\end{array}$ & $\begin{array}{c}\text { Quartz Dio } \\
0.40425 \\
0.44088 \\
0.49498\end{array}$ & $\begin{array}{l}0.05581(72) \\
0.05582(19) \\
0.05583(04)\end{array}$ & $\begin{array}{l}330.2 \\
359.3 \\
401.9\end{array}$ & $\begin{array}{l}344.7 \\
370.9 \\
408.3\end{array}$ & $\begin{array}{l}444 \pm 26 \\
445 \pm 8 \\
445 \pm 5\end{array}$ \\
\hline
\end{tabular}

Kah Shakes sequence

$3 \quad 45-62$

0.2

93

4.6

32

Micaceous Quartzite $\begin{array}{llllll}0.032484(07) & 0.56088 & 0.12529(17) & 206.1 & 452.1 & 2032\end{array}$
Mid-Cretaceous plutons

$\begin{array}{ccc}4 & 45-62 & 2 \\ 4 & 62-80 & 3 \\ 4 & 80-100 & 3 \\ \text { replicate } & 80-100 & 2 \\ 4 & 100-120 & 3 \\ 42 & >120 & 3\end{array}$

$\begin{array}{rlrrrr}5 & 45-80 & 4.3 & 1190 & 14.3 & 8037 \\ 5 & 80-100 & 6.3 & 449 & 5.7 & 412 \\ & & & & & \\ 6 & <25 & 3.6 & 692 & 8.9 & 6955 \\ 6 & 25-45 & 5.2 & 898 & 11.2 & 7421 \\ 6 & 45-62 & 9.0 & 725 & 9.5 & 5532\end{array}$

Union Bay Ultramafic Complex

$\begin{array}{llllll}0.013690(07) & 0.09061 & 0.048026(11) & 87.7 & 88.1 & 101 \pm 6\end{array}$ $\begin{array}{llllll}0.013219(07) & 0.08053 & 0.048053(09) & 84.7 & 85.2 & 101 \pm 4\end{array}$

$\begin{array}{llllll}0.103470(08) & 0.08926 & 0.048077(15) & 86.3 & 86.8 & 102 \pm 7\end{array}$

$\begin{array}{lrlllr}0.013476(07) & 0.08917 & 0.048019(09) & 86.3 & 86.7 & 99 \pm 10\end{array}$

$\begin{array}{llllll}0.013676(07) & 0.09074 & 0.048144(20) & 87.6 & 88.2 & 105 \pm 11\end{array}$

$\begin{array}{llllll}0.015931(09) & 0.10541 & 0.048011(18) & 101.9 & 101.7 & 99 \pm 18\end{array}$

Bell Island Tonalite

$\begin{array}{llllll}0.014910(09) & 0.09406 & 0.048132(07) & 90.7 & 91.3 & 105 \pm 7\end{array}$ $\begin{array}{llllll}0.014082(11) & 0.09331 & 0.048083(19) & 90.2 & 90.6 & 102 \pm 11\end{array}$

Eaton Point Granodiorite $\begin{array}{llllll}0.014784(10) & 0.09850 & 0.04834(08) & 94.6 & 95.4 & 115 \pm 15\end{array}$ $\begin{array}{llllll}0.014368(09) & 0.09524 & 0.04809(11) & 92.8 & 92.6 & 103 \pm 13\end{array}$ $\begin{array}{lllllr}0.014976(10) & 0.09897 & 0.04795(39) & 95.8 & 95.8 & 95 \pm 26\end{array}$ 
TABLE 2. (continued)

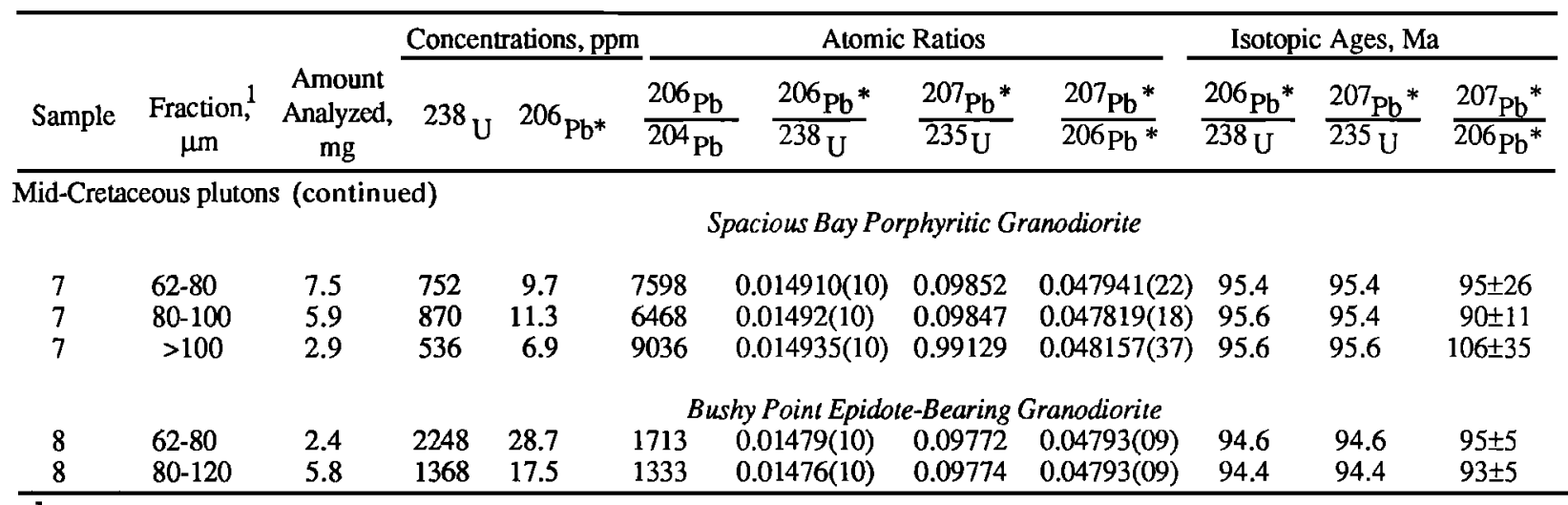

1 Fractions separated by grain size and magnetic properties. Magnetic properties are nonmagnetic using $20^{\circ}$ side and $2^{\circ}$ front slopes at 1.7 A on Franz Isodynamic Separator. Samples hand-picked to $99.9 \%$ purity prior to dissolution. Dissolution and chemical extraction technique modified from Krogh [1973].

2 Zircon fraction leached in a PFA teflon beaker on a hot plate with HF for 7 days at $\sim 100^{\circ} \mathrm{C}$ and fluxed twice for 2 days in $6 \mathrm{~N} \mathrm{HCl}$ prior to sample digestion.

3 Radiogenic: nonradiogenic correction based upon 40 picogram blank $\mathrm{Pb}(1: 18.78 ; 15.61 ; 38.50)$ and initial $\mathrm{Pb}$ approximations: $206 / 204=48.6 ; 207 / 204=15.6 ; 208 / 204=38.2$.

4 Decay constants used in age calculation: $\lambda^{238} \mathrm{U}=1.55125 \times 10^{-10}, \lambda^{235} \mathrm{U}=9.98465 \times 10^{-10}\left[\mathrm{Jaffey}\right.$ et al., 1971 ]; ${ }^{238} \mathrm{U} /{ }^{235} \mathrm{U}$ atom $=137.88$. Uncertainties $( \pm)$ in radiogenic ratios calculated by quadratic sum of total derivatives of ${ }^{238} \mathrm{U}$ and ${ }^{206} \mathrm{~Pb}^{*}$ concentration and ${ }^{207} \mathrm{~Pb}^{*} 206 \mathrm{~Pb}^{*}$ equations with error differentials defined as follows: (1) isotope ratio determinations from standard errors $(B / \mathrm{N})$ of mass spectrometer runs plus uncertainties in fractionation corrections based on multiple runs of NBS 981, 983, and U500 standards; (2) spike concentrations from range of deviations in multiple calibrations with normal solutions; (3) Spike compositions from external precisions of multiple isotope ratio determinations; (4) uncertainty in natural ${ }^{238} \mathrm{U} /{ }^{235} \mathrm{U}$ from Chen and Wasserburg [1981]; and (5) nonradiogenic $\mathrm{Pb}$ isotopic compositions from uncertainties in isotope ratio determinations of blank $\mathrm{Pb}$ and uncertainties in composition of initial $\mathrm{Pb}$ from estimates of regional variations based on references given above and consideration of rock type.

Rubin, 1989, 1990a]. On the basis of lithologic similarities, the presence of Precambrian detrital zircon, spatial proximity and tectonic setting, the Kah Shakes sequence is interpreted as correlative with the Yukon-Tanana terrane, which is now recognized within roof pendants and metamorphic screens as far south as latitude $59^{\circ}$, east of Juneau [Wheeler and McFeely, 1987; Gehrels et al., 1990; Gehrels et al., 1991; Rubin et al., 1990b; Rubin and Saleeby, 1991a].

\section{Gravina Sequence}

Upper Jurassic and Lower Cretaceous strata structurally overlie lower Paleozoic rocks on southeastern Cleveland Peninsula and locally lie unconformably over Triassic rocks on Annette and Gravina Islands (Figure 2) [Berg, 1972, 1973; Brew and Karl, 1987; Rubin and Saleeby, 1991c]. These strata belong to the Gravina-Nutzotin belt [Berg et al., 1972] which we informally call the Gravina sequence in southern southeastern Alaska. The sequence is exposed along the eastern margin of the Alexander terrane in much of southeast Alaska. Near Ketchikan, the Gravina sequence consists of two distinctive members; however, stratigraphic thickness is uncertain due to complex deformation.

On Cleveland Peninsula, the lower contact of the Gravina sequence is a thrust fault with the lower Paleozoic rocks of the Alexander terrane (Figure 5). There, the Gravina sequence has an approximate structural thickness of $15 \mathrm{~km}$. The lower member consists of argillite, calcareous argillite, waterlaid coarse pyroclastic deposits, tuff, lavas, and minor intrusive rocks. Pyroclastic volcanic deposits dominate the lower member on Cleveland Peninsula and contain massive to pillowed flows and flow breccia, commonly with clasts that are angular to subangular in shape. The age of the lower member is poorly constrained and, on the basis of lithologic and stratigraphic similarities with Upper Jurassic strata exposed on Gravina Island [Berg, 1973], the lower member on Cleveland Peninsula is interpreted as Late Jurassic in age.

The upper member consists of argillite, tuff, slate, and conglomerate and is well exposed on Cleveland Peninsula Revillagigedo, Gravina, and adjacent islands. The lower contact of the member is not exposed; however, locally the upper member overlies both the lower member of the Gravina sequence and unconformably overlies the upper Paleozoic and lower Mesozoic Alava sequence. The upper contact is a thrust fault with adjacent terranes. Lithologic units consist of argillaceous and tuffaceous turbidites and pebble to cobble conglomerate, with a total structural thickness of $900 \mathrm{~m}$. Conglomerate beds occur in a distinctive mappable horizon, exposed between southeastern Cleveland Peninsula and southeastern Revillagigedo Island. Clasts in the conglomerate yield $\mathrm{U}-\mathrm{Pb}$ zircon ages of $154 \mathrm{Ma}$ to $158 \mathrm{Ma}$ Rubin and Saleeby, 1991c]. These Late Jurassic ages for the granitic clasts provide a maximum age for deposition. Based on geologic relations with similar strata exposed to the north and sparse fossil data in the Ketchikan area [Berg and Cruz, 1982], an Early Cretaceous age is inferred for the upper member clastic and tuffaceous strata.

\section{Mid-Cretaceous Intrusive Rocks}

Mafic and ultramafic rocks. Mid-Cretaceous mafic and ultramafic bodies underlie part of Cleveland Peninsula, Revillagigedo, and Duke islands (Figure 2). The ultramafic complexes form a linear belt that spans approximately 560 


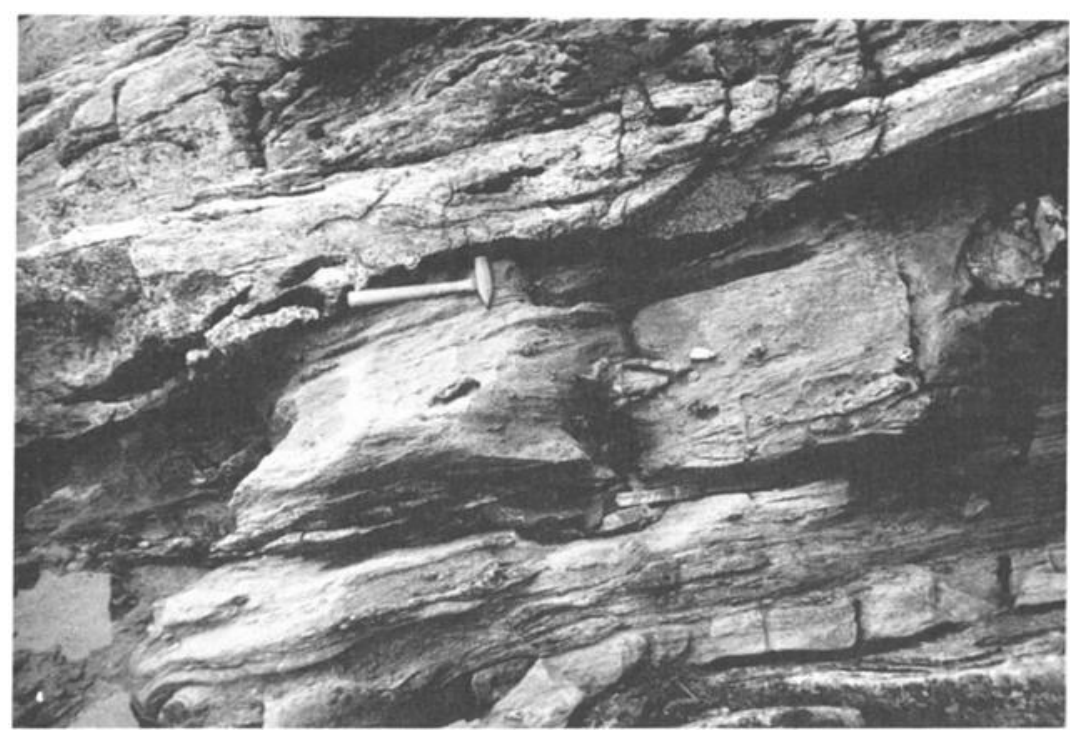

Fig. 4. Amphibolite-facies rocks of quartzite and marble in the Kah Shakes sequence exposed north of Rudyerd Inlet on the east- side of Behm Canal.

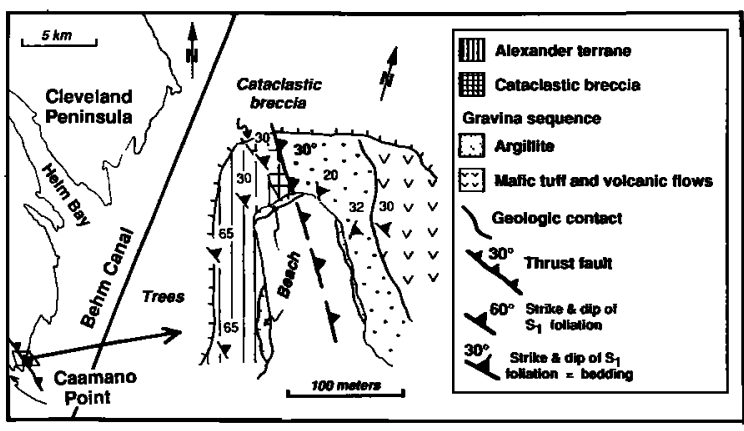

Fig. 5. Geologic sketch map of the contact between the Alexander terrane and the Gravina sequence, exposed in an unnamed cove northeast of Caamano Point, southern Cleveland Peninsula. Regional location is shown in inset (Ketchikan C-6 quadrangle).

$\mathrm{km}$, from northwestern British Columbia to southeast Alaska [Taylor, 1967]. The complexes intrude rocks of the Alexander terrane, and Gravina and Alava sequences. The bodies occur as zoned ultramafic complexes ranging in composition from dunite, in the center, to pyroxenite and hornblende pyroxenite on the outer border [Taylor, 1967; Irvine, 1967, 1974]. Interstitial gabbroic pods and lenses are present in the hornblendite. Plagioclase from the gabbro is extensively saussuritized. Zircon from gabbro pods and veins within hornblendite in the Union Bay Ultramafic Complex (Table 1) yield discordant $238 \mathrm{U}-206 \mathrm{~Pb}$ ages ranging from 84.7 to 88.1 Ma (sample 4, Table 2). A leached coarse zircon fraction yields a concordant $238 \mathrm{U}-206 \mathrm{~Pb}$ age of $\sim 101.5 \mathrm{Ma}$ (sample 4 , Table 2). Five fractions are dispersed off concordia (Figure 6), which may reflect later disturbance of the U-Pb isotopic systems in zircon. The ${ }^{238} \mathrm{U}-206 \mathrm{~Pb}$ and ${ }^{235} \mathrm{U}-207 \mathrm{~Pb}$ ages are slightly discordant at $-86 \mathrm{Ma}$; however, the ${ }^{207} \mathrm{~Pb}-206 \mathrm{~Pb}$ ages are older and range between 99 and 105 Ma (Table 2). Discordance probably reflects later isotopic disturbance of

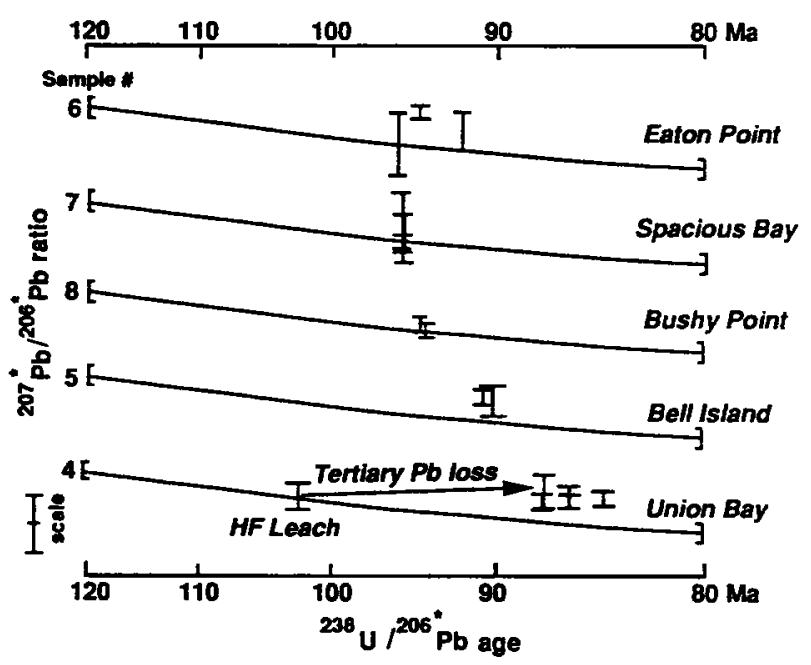

Fig. 6. Concordia plotted separately for each sample, with scale for ${ }^{207} \mathrm{~Pb} /{ }^{206} \mathrm{~Pb}$ ratio shown. Each segment contains data points and error bars for indicated samples of igneous rocks from Cleveland Peninsula and Bell Island. Bars at ends of concordia segments show uncertainty in $207206 \mathrm{~Pb}$ values of concordia based on uncertainties in ${ }^{238} U$ and ${ }^{235} U$ decay constants from Mattinson's [1987] treatment of Jaffey et al. [1971] data. Concordia diagram after Tera and Wasserburg [1972]. Linear regression and errors in lower and upper intercepts are adapted from York [1969].

Cretaceous zircon populations rather than inheritance from older xenocrystic zircon. This interpretation is consistent with the lack of compositional zoning or optically distinguished cores in zircon. Widespread Miocene volcanism, hydrothermal activity and associated fluid flow have been recognized in southeast Alaska [Magaritz and Taylor, 1986] and may have been responsible for the isotopic disturbance in the Union Bay zircon. On the basis of the foregoing, the gabbroic pods 
within the hornblendite are assigned an approximate age of $102 \mathrm{Ma}$, which represents the oldest ${ }^{207} \mathrm{~Pb}-206 \mathrm{~Pb}$ age for the sample and the $238 \mathrm{U}-206 \mathrm{~Pb}$ age for the leached zircon fraction. K-Ar analyses on hornblende and biotite of the ultramafic bodies yield 100-110 Ma cooling ages [Lanphere and Eberlein, 1966]. K-Ar analyses on the Union Bay ultramafic body are consistent with the $108 \mathrm{Ma} \mathrm{U}-\mathrm{Pb}$ zircon age obtained from a pegmatite associated with the Duke Island ultramafic complex [J.B. Saleeby, unpublished data, 1990].

Quartz diorite and granodiorite. Northern Revillagigedo Island and Cleveland Peninsula are underlain by a composite batholith composed of massive to foliated, medium- to coarsegrained hornblende quartz diorite, tonalite, and granodiorite (Figure 2). The Bell Island Pluton on northern Revillagigedo and Bell Islands and northern Cleveland Peninsula is part of the composite body (Figure 2). Subhorizontal dikes and veins of quartz-feldspar pegmatite and subordinate agmatite are present throughout the batholith. The rocks contain varying proportions of plagioclase, microcline, quartz, hornblende, and brown biotite. Apatite, zircon, sphene, ilmenite, and magnetite occur as accessory minerals. A leucocratic quartz diorite (Bell Island Pluton, sample 5, Table 1) yields U-Pb zircon age of $90.5 \pm 7 \mathrm{Ma}$ (Table 2). These data are consistent with a preliminary $\mathrm{U}-\mathrm{Pb}$ zircon age of $89 \mathrm{Ma}$ reported by Arth et al. [1988]. K-Ar analyses yield hornblende cooling ages that range from 86 to $55.5 \mathrm{Ma}$, and biotite cooling ages that range from 74 to $49 \mathrm{Ma}$ [Smith and Diggles, 1981]. The batholith intrudes the Gravina sequence on northern Cleveland Peninsula, the Kah Shakes sequence on east Behm Canal, and the Alava sequence on western Revillagigedo Island.

Plagioclase porphyritic granodiorite, quartz diorite, and tonalite. Elongate stocks, plutons, sills, and dikes of plagioclase porphyry and quartz diorite intrude much of Revillagigedo and adjacent islands and Cleveland Peninsula (Figure 2). The Eaton Point Pluton, exposed on northem Cleveland Peninsula, is assigned to this unit. Locally, the rocks contain abundant plagioclase phenocrysts, which make up to $50 \%$ of the rock and range between 1 and $4 \mathrm{~cm}$ in diameter. The groundmass contains fine-grained quartz, microcline, biotite, minor homblende, epidote, and garnet. Euhedral garnet occurs within cores of plagioclase, but it also occurs within the groundmass. Anhedral to euhedral epidote is interstitial to plagioclase crystals. The plutons intrude metasedimentary and metavolcanic rocks assigned to the Gravina and Alava sequences, and locally the Alexander terrane (?), and have narrow contact aureoles that overprint the metamorphic foliation. The sills and dikes are parallel with foliation and locally crosscut the metamorphic framework rocks, increasing in abundance toward the east. The Eaton Point Pluton, a medium-grained granodiorite, yields a U-Pb zircon age of $95 \pm 3 \mathrm{Ma}$ (sample 6, Tables 1 and 2). A plagioclase porphyritic granodiorite phase of the Eaton Point Pluton yields a U-Pb age of $95 \pm 1 \mathrm{Ma}$ (sample 7, Tables 1 and 2). A granodiorite phase of the Bushy Point Pluton (Bushy Point Pluton, sample 8, Table 1) yields a U-Pb age of 94.5 $\mathrm{Ma}$ (Table 2). These data are consistent with a preliminary discordant ${ }^{238} \mathrm{U}-206 \mathrm{~Pb}$ zircon age of $92.7 \mathrm{Ma}$ reported by Arth et al. [1988]. K-Ar analyses yield $82 \pm 2.5 \mathrm{Ma}$ (hornblende) and $86 \pm 2.7$ Ma (biotite) cooling ages [Smith and Diggles, 1981].

Epidote-hornblende tonalite, quartz diorite, and granodiorite. Epidote-bearing granodiorite, quartz diorite, and tonalite occur as elongate plutons on southwestem and part of northeastern Revillagigedo Island (Figure 2). These distinctive plutons continue as a belt farther north into the Petersburg and Juneau area (Figure 1) [Brew and Morrell, 1983]. The petrology and mineral chemistry of the epidote-bearing plutons are discussed by Zen [1985, 1988], Zen and Hammarstrom [1984], Hollister et al. [1987], and Cook et al. [1991]. The rocks are characterized by apple-green, euhedral epidote and contain quartz, plagioclase, microcline, hornblende, biotite, and locally garnet. Magnetite, ilmenite, apatite, zircon, sphene, and allanite occur as accessory minerals. The plutons are usually massive in the interior and foliated along their margins and intrude the Gravina and Alava sequences and, locally, the Alexander terrane. The bodies display intrusive contacts and are locally in fault contact with adjacent metasedimentary and metaplutonic rocks. U-Pb zircon ages for the plutons range between $94 \mathrm{Ma}$ and $101 \mathrm{Ma}$, and locally zircon systematics reveal Proterozoic inheritance (e.g., the Moth Bay Pluton [Rubin and Saleeby, 1987]). A homblende $\mathrm{Ar}^{40} / \mathrm{Ar}^{39}$ plateau age of $97 \mathrm{Ma}$ is reported by Sutter and Crawford [1985] for the Moth Bay Pluton.

$U-P b$ zircon geochronology. Mid-Cretaceous ages were determined for all four plutons on northern Cleveland Peninsula and Revillagigedo and Bell islands. The porphyritic granodiorite of Spacious Bay (sample 7) shows $95 \mathrm{Ma}$ concordance of all the fractions, with slight dispersion of its coarse fraction off concordia which probably reflects minor contamination by older zircon from its country rocks (Figure 6). The Eaton Point granodiorite (sample 6) is discordant, with its coarse fraction lying on concordia at $\sim 95.8 \mathrm{Ma}$ (Figure 6). The Bushy Point epidote-bearing granodiorite (sample 8) yields a U-Pb age of $94.5 \mathrm{Ma}$, with $\mathrm{Pb}-\mathrm{Pb}$ ages of $95 \pm 5$ and $93 \pm 5 \mathrm{Ma}$, respectively (Table 2 ). The two finer fractions are dispersed off concordia, which may reflect later disturbance of the $\mathrm{U}-\mathrm{Pb}$ isotopic systems in zircon, perhaps due to the emplacement of the younger Bell Island pluton (sample 5) or Miocene hydrothermal activity discussed above. A younger isotopic disturbance is recorded by K-Ar ages [Smith and Diggles, 1981]. Quartz dioritic rocks yield K/Ar ages of $\sim 74 \mathrm{Ma}$ (biotite) and 81.8 to $79 \mathrm{Ma}$ (hornblende) on northern Cleveland Peninsula and on adjacent islands southwest of Bell Island (uncertainties in the K-Ar dates are reported at the $1 \sigma$ level). The dispersion of the finer fractions may also be due in part to contamination with older zircon. Disturbance of the U-Pb isotopic systems may have been more complex than a single episode of lead loss, perhaps due to a combination of $\mathrm{Pb}$ loss and contamination of older zircon. The quartz diorite of Bell Island (sample 5) yields a U-Pb age of $90.5 \mathrm{Ma}$, with older $\mathrm{Pb}-\mathrm{Pb}$ ages of $102 \pm 11$ and $105 \pm 7$ $\mathrm{Ma}$, respectively (Table 2). A $90 \mathrm{Ma}$ age is consistent with nearly concordant ${ }^{206} \mathrm{~Pb} / 238 \mathrm{U}$ zircon ages of $\sim 89$ and $91 \mathrm{Ma}$ [Arth et al., 1988]; $\mathrm{Pb}-\mathrm{Pb}$ ages were not reported in their study.

\section{STRUCTURAL GEOLOGY}

Only recently have mid-Cretaceous basement-involved thrust faults and associated nappe structures been recognized in southern southeast Alaska [Berg et al., 1972, 1988; Crawford et al., 1987; Rubin et al., 1990a; Rubin and Saleeby, 1991b]. Near Ketchikan, deformation of lower Paleozoic to midCretaceous supracrustal and plutonic rocks is localized along the eastern boundary of the Alexander terrane and is characterized by an imbricate series of west- to southwestvergent thrust sheets. Based on regional geologic and geochronologic relations, the west-vergent fold and thrust system was active between about 113 and $89 \mathrm{Ma}$. Younger intrusive rocks do not display the mid-Cretaceous thrust-related fabrics. Both the younger intrusive rocks and the rocks affected by mid-Cretaceous deformation were subsequently affected by late Paleocene to early Eocene deformation and associated uplift [Hollister, 1982; Crawford et al., 1987; Gehrels and McClelland, 1988; Gehrels et al., 1992; 
McClelland et al., 1992,a, b]. Deformation and metamorphism which preceded mid-Cretaceous tectonism are discussed by McClelland and Gehrels [1990] and Saleeby and Rubin [1990b] and appear to represent pre-Late Jurassic dextral strike-slip dismemberment of the Alexander terrane, possibly during its accretion, and subsequent Late Jurassic-earliest Cretaceous extension across the accretionary suture.

Mid-Cretaceous deformation occurred during three main episodes that correspond with the emplacement of sill-like

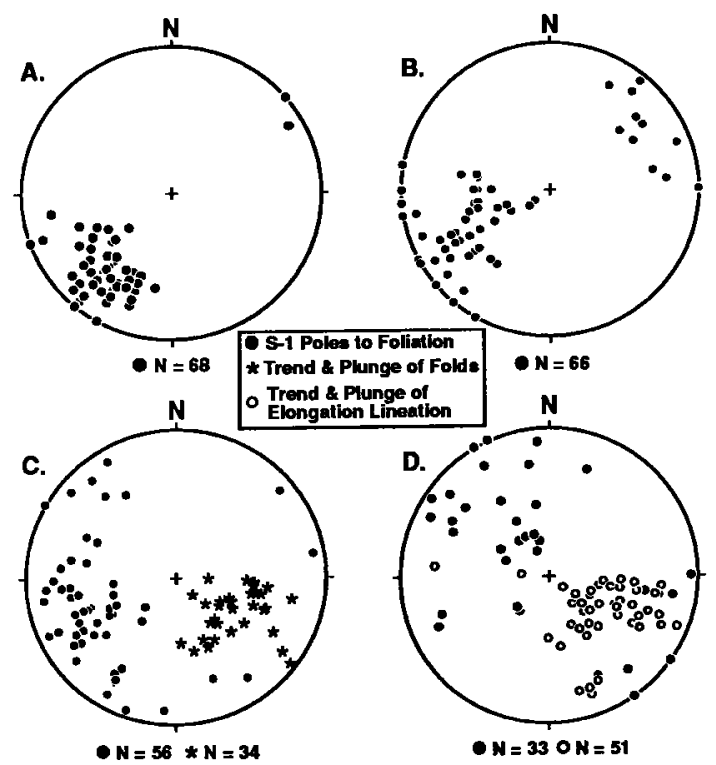

Fig. 7. Lower hemisphere, equal-area plot showing, (a) poles to foliation surfaces on northwest Cleveland Peninsula, (b) poles to foliation surfaces on southern Cleveland Peninsula, (c) trend and plunge of small-scale folds and poles to foliation surfaces in higher level thrust nappes on northern Cleveland Peninsula, and (d) poles to foliation surfaces, and trend and plunge of elongation lineation in higher level thrust nappes. plutonic bodies. Older fabrics record ductile southwest-vergent folding and faulting and regional metamorphism, whereas younger fabrics are characterized by crenulation cleavage and thrust faulting and associated folding. Structural style varies along the strike of the orogenic zone and between structural levels due to changes in rock type, overall metamorphic grade, and proximity to plutonic rocks. Cross sections cannot be rigorously balanced duc to (1) changes in bulk-rock volume, (2) the presence of ductile strain and associated plastic flow, and (3) the absence of exposed step-up angles along thrust faults.

\section{First-Generation Mid-Cretaceous Thrust Faults}

The lowest thrust sheets consist of lower Paleozoic schist, marble, and metaigneous rocks of the Alexander terrane (Figures $3 \mathrm{a}$ and $3 \mathrm{~b}$ ). These rocks are characterized by mesoscopic folding, nonpenetrative foliation, and thrust faulting and display lower-greenschist facies mineral assemblages. Early deformational fabrics $\left(D_{1}\right)$ are characterized by mesoscopic northeast dipping foliation surfaces $\left(S_{1}\right)$ and a bedding-foliation intersection lineation $\left(L_{0 \times 1}\right)$. Thrust faults trend northwest and dip moderately to the northeast. The Gravina sequence structurally overlies the Alexander terrane, and on Cleveland Peninsula the sequence consists of six separate west-vergent thrust sheets (Figure 3b). The basal thrust fault separating the Alexander terrane from the Gravina sequence crosscuts the metamorphic foliation, displays a cataclastic fabric, and juxtaposes shallowly dipping Gravina sequence argillite over the moderately dipping lower Paleozoic Descon Formation of the Alexander terrane (Figure 5). Lower Paleozoic and upper Proterozoic crystalline rocks of the Alexander terrane form structural basement to the thrust belt. In general, thrust faults trend northwest, and their orientation generally follows the regional metamorphic foliation (Figure 2).

There is a predominance of moderate, northeast-dipping foliation surfaces (Figure 7a) which are axial planar to asymmetric, west- to southwest vergent folds. These asymmetric folds (Figure 8) are truncated by thrust faults and

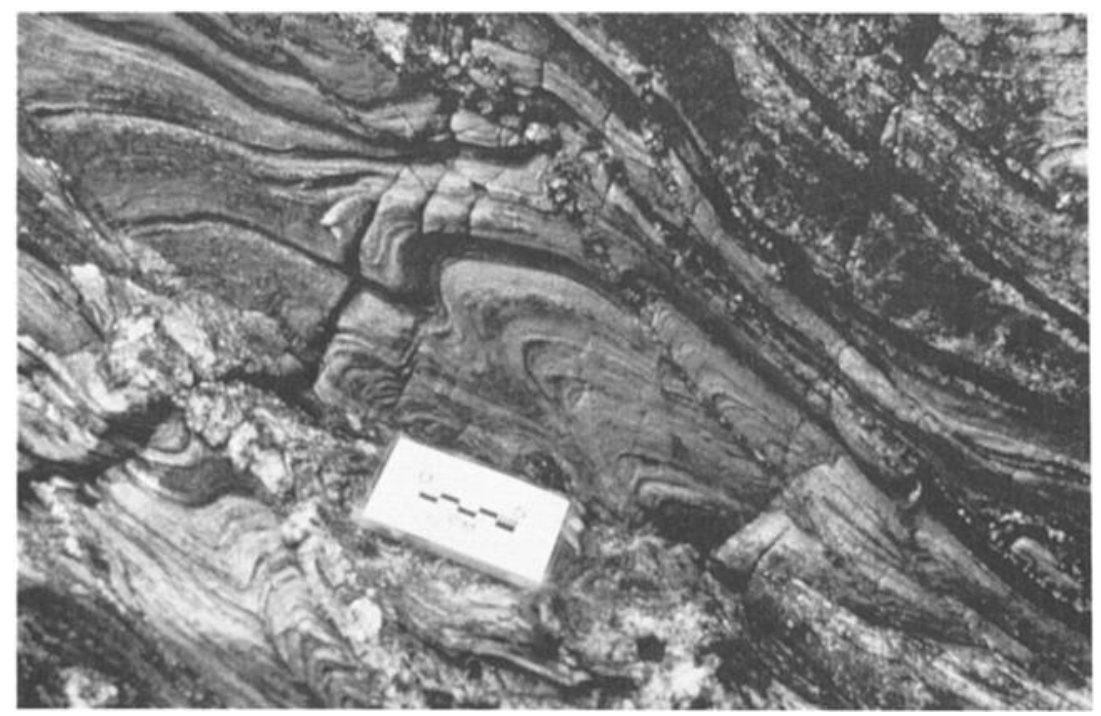

Fig. 8. Asymmetric folds truncated by moderately dipping thrust faults in the Permian part of the Alava sequence, exposed on Revillagigedo Island. This fault zone places Permian marble and metabasalt over Triassic carbonaceous pelitic schist. 
appear kinematically linked to the thrust faults. In well-bedded strata, compositional layering and foliation are commonly subparallel, whereas massive volcanic flows and breccias do not display a foliation and were deformed as rigid bodies. Foliation parallels flattening fabrics that are well developed within conglomeratic horizons. The $S_{1}$ foliation is defined by mica grains and elongate, slightly flattened plagioclase grains that are parallel or subparallel to compositional layering. Rocks of the Gravina sequence are structurally overlain to the northeast, along the Point Francis fault system (Figure 2), by upper greenschist facies rocks belonging to the upper Paleozoic and lower Mesozoic Alava sequence. Moderately dipping, west- to southwest-vergent ductile fault zones are characteristic of the structurally higher thrust sheets. There is a predominance of moderate northeast-dipping foliation surfaces $\left(S_{1}\right)$ which are axial planar to asymmetric, west- to southwest-vergent folds (Figures $7 \mathrm{~b}$ and $7 \mathrm{c}$ ). These asymmetric folds are truncated by thrust faults (Figure 8 ) and appear to be kinematically linked, as above, to thrust faults. The Alava sequence is locally structurally overlain by amphibolite facies rocks assigned to the lower Paleozoic Kah Shakes sequence. Kah Shakes rocks are characterized by attenuated fold limbs and a moderately developed down-dip elongation lineation that is parallel to fold axes. On northern Cleveland Peninsula and northeast Revillagigedo Island (Figure 2), Kah Shakes foliation trends northwest.

Metamorphic grades increase from lower to higher structural levels. In the lowest structural level, phyllite in the Gravina sequence contains white mica, chlorite, epidote, plagioclase, and calcite which are typical of lower greenschist facies metamorphism. Fossils are preserved in carbonaceous limestone and argillite. Contact metamorphic aureoles are present near plutons and are best observed on Spire Island located northeast of Annette Island (Figure 2). There relict andalusite, replaced by white mica, occurs in phyllite in a narrow zone adjacent to the Spire Island diorite, which indicates low pressure and low to moderate temperature conditions. Gamet porphyroblasts occur in phyllite of the Gravina sequence adjacent to the Union Bay ultramafic complex. There, the regional fabric, defined by the planar orientation of biotite and white mica, overprints the contact metamorphic aureole, showing that the emplacement of the ultramafic complex preceded regional melamorphism.

Mafic volcanic rocks are widespread in the lower structural levels and contain relict euhedral phenocrysts of clinopyroxene, hornblende, and plagioclase in a fine-grained microgranular matrix of relict pyroxene, amphibole, metamorphic actinolite, chlorite, epidote, albite, quartz, white mica, and calcite, typical of low-temperature greenschist-facies metamorphism. Relict clinopyroxene and hornblende phenocrysts in the volcanic strata are unstrained and are partially replaced by chlorite and white mica. Preliminary oxygen isotopic analyses on mafic phenocrysts indicate primary igneous $\delta^{180}$ values which imply that the phenocrysts did not interact with hydrothermal fluids (C.M. Rubin and H. P. Taylor, Jr., unpublished data, 1987). Andalusite in contact aureoles, lower greenschist facies metamorphic mineral assemblages, and abundant relict phenocrysts in volcanic strata imply pressures no greater than 3.5 kbar [e.g., Holdaway, 1971] and generally low temperatures $\left(<400^{\circ} \mathrm{C}\right.$, [e.g., Tumer, 1981]) in the lower structural levels.

Toward the east, in successively higher structural levels, biotite and gamet appear, indicating upper greenschist facies metamorphism. Locally, staurolite is present in pelitic strata, and hornblende-plagioclase-garnet \pm epidote mineral assemblages are present in mafic metavolcanic rocks. These lower amphibolite mineral assemblages, combined with pressure estimates obtained for the Moth Bay Pluton, and based on aluminium content in hornblende [Zen and Hammarstrom, 1984], and the experimental calibration of Johnson and Rutherford [1989] imply pressure of 5 to $6 \mathrm{kbar}$ and temperatures of $-550^{\circ} \mathrm{C}$. With the same geobarometer, pressure estimates for the Bushy Point Pluton, located to the northeast (Figure 2) [Zen and Hammarstrom, 1984], yield pressures in excess of $6 \mathrm{kbar}$. In higher structural levels, on northem Cleveland Peninsula and Revillagigedo Island (Figure 2), kyanite \pm sillimanite schist occur as either bladed crystals up to $1 \mathrm{~cm}$ long or bundles of rods which crosscut the dominant northeast trending foliation. The presence of kyanite-staurolite mineral assemblages, midcrustal level plutons (e.g., Bushy Point Pluton), and the occurrence of tonalite sills and dikes that lack contact aureoles suggest upper amphibolite temperatures of at least $550^{\circ} \mathrm{C}$ and pressures of 6-7 kbar [e.g., Turner, 1981] in the higher structural thrust sheets.

\section{Second-Generation Mid-Cretaceous Thrust Faults}

The Southern Revillagigedo Island fault zone (Southern Revillagigedo Island shear zone of Cook et al. [1991]), exposed on southwestern Revillagigedo Island between Thorne Arm and Carroll Inlet (Figures 2 and 9), is a major structural boundary in the Ketchikan area. The fault zone dips moderately northeastward and juxtaposes mid-Cretaceous tonalitic sills, dikes, and a large pluton, along with their host rocks, over nondeformed mid-Cretaceous sills and dikes and Gravina sequence metasedimentary and metavolcanic rocks (Figure $3 \mathrm{~b}$ ). To the northwest, the fault zone cuts tonalitic sills and segments of the Moth Bay Pluton. Regional metamorphic and structural fabrics are truncated by the fault zone. Fabrics produced by simple shear are well preserved in the fault zone. Igneous rocks in the fault zone commonly display blastomylonitic textures, and, locally, relict igneous textures are completely overprinted by ultramylonite consisting of very fine grained quartz-bioite-epidiote mineral assemblages. Rotated plagioclase porphyroclasts, asymmetric recrystallized tails, and S-C fabrics in the igneous rocks suggest top to the northwest or an oblique, sense of motion. Brecciated, oblate clasts of weakly deformed plutonic rocks (Figure 10) are surrounded by a foliated micaceous, locally mylonitic matrix and commonly display $S$-C fabrics which indicate a similar sense of shear. The timing of motion on the Black Mountain fault is constrained by two lines of evidence. The fault zone affects plutonic rocks with a U-Pb zircon age of 101 Ma [Rubin and Saleeby, 1987], so much of the deformation must have postdated the emplacement of the pluton. Although much of the deformation postdates the 101

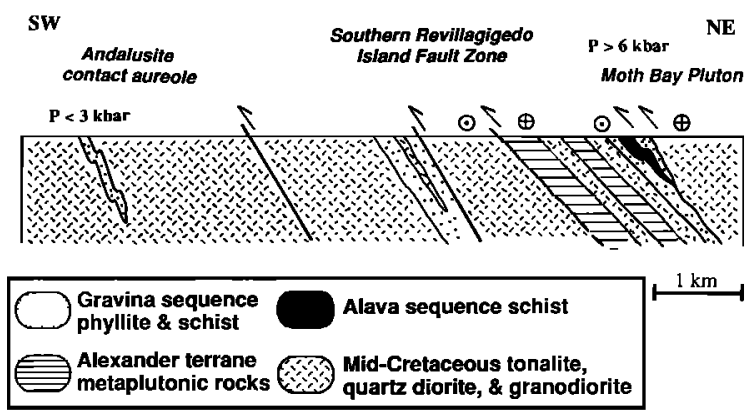

Fig. 9. Geologic cross section across the Southern Revillagigedo Island fault zone, exposed on southwestern Revillagigedo Island. 


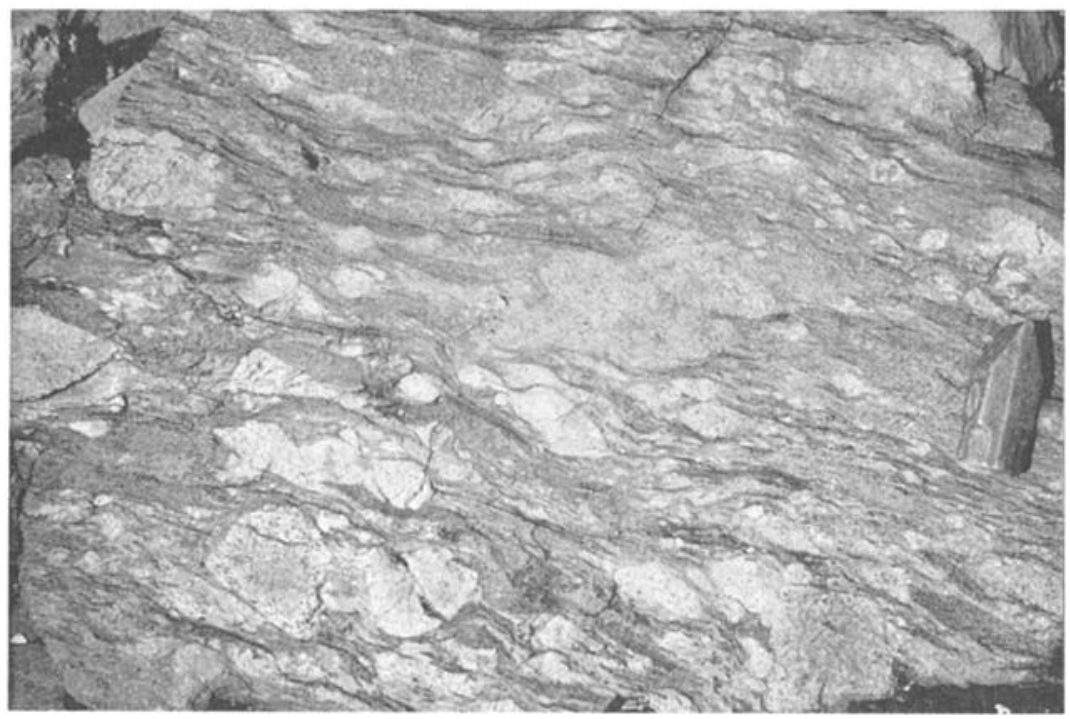

Fig. 10. Weakly deformed tonalitic clasts in a mylonitic matrix. These fabrics developed within the Southem Revillagigedo Island fault zone on southem Revillagigedo Island.

Ma Moth Bay pluton, contact mineral assemblages locally overprint blastomylonitic fabrics in the fault zone, implying that intrusion and contact metamorphism were partly contemporaneous with faulting.

The fault zone probably extends to the north along the southwest side of Revillagigedo Island (Figure 2), where a thrust fault strikes approximately $\mathrm{N} 20^{\circ}-30^{\circ} \mathrm{W}$. Associated southwest-vergent asymmetric folds trend $S 60^{\circ}-70^{\circ} \mathrm{E}$ and plunge moderately to the southeast (Figure 11a). Numerous quartz veins are present in the fault zone. In the footwall, Gravina sequence rocks are well bedded and are characterized by lowermost greenschist facies mineral assemblages and unstrained relict phenocrysts. On the basis of these relations, the footwall block appears to have undergone minor finite strain and metamorphism. In contrast, the upper plate contains rocks that locally have biotite-grade greenschist facies mineral assemblages and well-developed foliation surfaces and that are cut by numerous deformed sills and dikes of diorite. As the fault zone is approached, abundant quartz veins appear in the metamorphosed hanging wall lithologies.

The amount of displacement on the fault zone is difficult to estimate. By using differences in metamorphic and igneous pressures on rocks exposed on either side of the fault, however, a qualitative displacement estimate can be obtained. The presence of kyanite-staurolite schist gives a minimum pressure of $4.5 \mathrm{kbar}$ for the hanging wall metasedimentary rocks. In addition, thermobarometric estimates for the upper plate were determined by Cook et al. [1991] and range from $\sim 7.9 \pm 0.6 \mathrm{kbar}$ to $\sim 8.5 \pm 1 \mathrm{kbar}$. On the basis of aluminum contents in hornblende from the Moth Bay Pluton [Hammarstrom and Zen, 1986; Cook et al., 1991] and using the experimental calibration of Johnson and Rutherford [1989], a pressure range from 6.0 to $7.9 \mathrm{kbar}$ is recorded for the pluton exposed in the upper plate of the thrust. The ranges in pressure may be due to variability of $\mathrm{Al}^{\mathrm{T}}$ in hornblende. These pressures are in agreement with the inferred estimated crystallization pressure for the Moth Bay pluton based on the presence of magmatic epidote [Zen and Hammarstrom, 1984]. Pressures of 3.0-3.5 kbar in the lower plate can be inferred by the andalusite contact aureole and associated regional lower greenschist facies mineral assemblages. Assuming that pressure estimates are correct and were locked in prior to faulting, the hanging wall was uplifted $-14 \mathrm{~km}$ with respect to the footwall. A minimum dip-slip displacement of
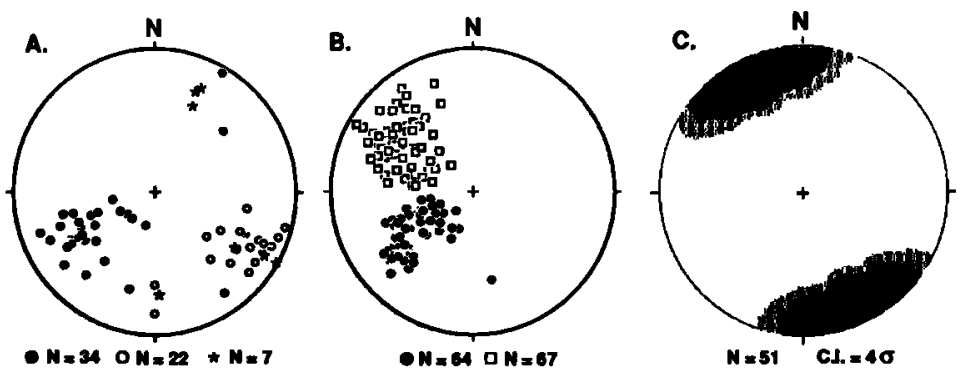

Fig. 11. Lower hemisphere equal-area plot showing (a) poles to foliation surfaces, small-scale folds, and lineations along the southern Revillagigedo fault zone, (b) poles to foliation surfaces and small-scale folds of $D_{1}$ and $D_{2}$ fabrics, and (c) Contour of poles to dike orientation. C.I. is confidence interval [after Kamb, 1959]. Solid circles are $S_{1}$ foliation; Open squares are $S_{2}$ foliation; Asterisks are trend and plunge of small scale folds; Open circles are trend and plunge of lineation. 
approximately $24 \mathrm{~km}$ is inferred across the Southern Revillagigedo Island fault zone, assuming the fault was not subsequently rotated during post-Cretaceous time. Although elongation lineations trend oblique to the dip of the fault, concurrent strike-slip displacement across the fault cannot be quantified.

\section{Third-Generation Ductile Fault Zones}

Steeply dipping, north- to northwest-striking ductile fault zones crosscut the earlier $\left(S_{1}\right)$ fabrics in the eastern and northern part of the thrust belt (Figure 2). The fault zones are characterized by a strongly developed foliation which reorients earlier $S_{1}$ fabrics. Structural relations suggest that reverse faulting occurred after $F_{1}$ folding and associated thrust faulting, and possibly during the late stages of the emplacement of the mid-Cretaceous tonalite plutons. The relationships between thrust faulting, regional metamorphism, and later reverse faulting described below suggest that these are likely the result of a single progressive deformational event.

The northern Revillagigedo Island fault zone, exposed on the northwestem portion of Revillagigedo Island (Figure 2), dips steeply northeastward. In the fault zone, earlier northwesttrending $S_{1}$ fabrics (regional foliation) are preserved within a compositionally banded biotite schist and are completely transposed and tightly refolded within a series of ductile shear zones (Figure 12). The metamorphic rocks are cut by numerous quartz veins in which northwest-trending $S_{1}$ quartz veins are folded and attenuated; later quartz veins formed along the axial surfaces of $S_{2}$ folds. Most axial planes of $S_{2}$ folds trend between $N 40^{\circ}$ to $60^{\circ} \mathrm{W}$ and dip from $70^{\circ}$ to the northeast to $90^{\circ}$. Folds in banded biotite schist are disharmonic, generally tight to isoclinal and commonly asymmetric. The fold axes trend $S 40^{\circ}$ to $80^{\circ} \mathrm{E}$ and plunge moderately to the southeast. The limbs of the folds are extremely attenuated and locally display isolated asymmetric floating hinges. A welldeveloped elongation lineation is associated with $S_{2}$ foliation and trends $\mathrm{S} 40^{\circ}$ to $60^{\circ} \mathrm{E}$, plunging moderately to steeply to the southeast.

The northern Revillagigedo Island fault zone separates supracrustal metamorphic sequences of widely differing metamorphic grade. In the footwall block, south of the fault zone, supracrustal rocks display garnet greenschist-facies mineral assemblages, whereas to the north in the hanging wall, kyanite-bearing amphibolite grade schist and the midCretaceous Bell Island pluton are present. On the basis of these geologic relations, top to the north or a reverse-sense of motion is recorded. The magnitude of displacement on the

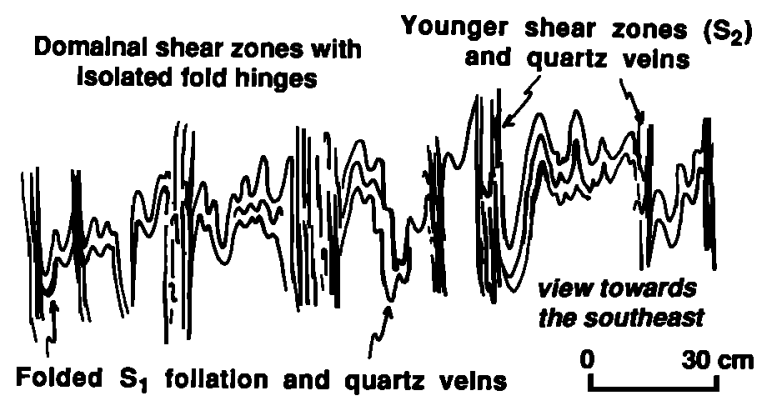

Fig. 12. Geologic sketch of transposed foliation (S1) and associated isoclinal folds in banded kyanite schist along the Northern Revillagigedo fault zone. Elongation lineation dips moderately to the southeast. fault zone is difficult to estimate, due to the absence of stratigraphic cutoffs along the fault zone. A minimum of displacement of $7 \mathrm{~km}$ between the hanging wall and footwall is inferred, on the basis of metamorphic pressure estimates on pelitic supracrustal rocks exposed on either side of the fault zone. Strike-slip displacement across the fault cannot be quantified; however, on the basis of the southeast plunging stretching lineation associated with asymmetric folds, substantial displacement may be likely.

\section{Zonation of the Thrust Belt}

High-angle reverse faults, represented by the northern and southern Revillagigedo fault zones, divide the thrust belt into three of the four mid-Cretaceous structural domains shown in Figure 13. The subsurface geometry of the thrust faults and ductile reverse faults is not accurately known. By combining available geologic and petrologic constraints, a reasonable and internally consistent subsurface geometry can be constructed. Domain 1, located on the western portion of the thrust belt, consists of rocks that have undergone little finite strain and that contain low-temperature and low-pressure metamorphic mineral assemblages. Typically, rocks in this domain are well bedded and consist entirely of the Alexander terrane and Gravina sequence. The central region, domain 2, consists of imbricate thrust nappes of rocks that are assigned to the Alexander terrane and Gravina and Alava sequences. The rocks display well-developed metamorphic fabrics and contain medium pressure and temperature-sensitive metamorphic minerals. The appearance of mid-Cretaceous tonalite and granodiorite is characteristic of this domain. Highertemperature and higher-pressure (?) mineral assemblages are recorded by rocks in domain 3, which consists of the Alexander terrane, and Kah Shakes, Alava, and Gravina sequences. There, amphibolite facies rocks are dominant. Well-developed elongation lineations, highly attenuated fold limbs, and polyphase fabrics characterize this domain. Metamorphic rocks are intruded by tonalitic sills and dikes, and, locally, lit-par-lit structures are well developed in the high-grade gneisses of domain 3. Typically, rocks in Domain 3 are intruded by late Paleocene intrusive rocks and are overprinted by early Tertiary extensional deformation.

Mid-Cretaceous shortening was accommodated through the development of crenulation cleavage and is best exposed near Naha Bay along the northwestern shore of Revillagigedo Island (Figure 2). This fabric is defined by mesoscopic, northeast trending spaced cleavage $\left(S_{2}\right), S_{1}-S_{2}$ intersection lineation $\left(L_{1 \times 2}\right)$, and associated west- to northwest-vergent asymmetric kink folds (Figure 11b). The cleavage forms small-scale folds in phyllite, whereas in massive metavolcanic rocks a planar widely spaced cleavage is present (Figure 11b). The cleavage is defined by the concentration of phyllosilicates in fold limbs. New mineral growth parallel to the kink fold axial planes consist of fine-grained biotite and gamet. Quartz grains are recrystallized and slightly flattened to the axial planes.

\section{Late Paleocene Deformation}

Paleocene and younger (?) deformation has affected rocks on the western margin of the Coast Plutonic Complex (Figure 2). Deeper structural levels are exposed along the eastern edge of the Alexander terrane and the Alava sequence and are dominated by low to moderate east-dipping sheets of schist, gneiss, and phyllonite termed the east Behm Canal gneiss complex [Saleeby, 1987; Saleeby and Rubin, 1990a]. Shallow northeast-plunging elongation lineations are common; 


\section{Domain I}

Domain II

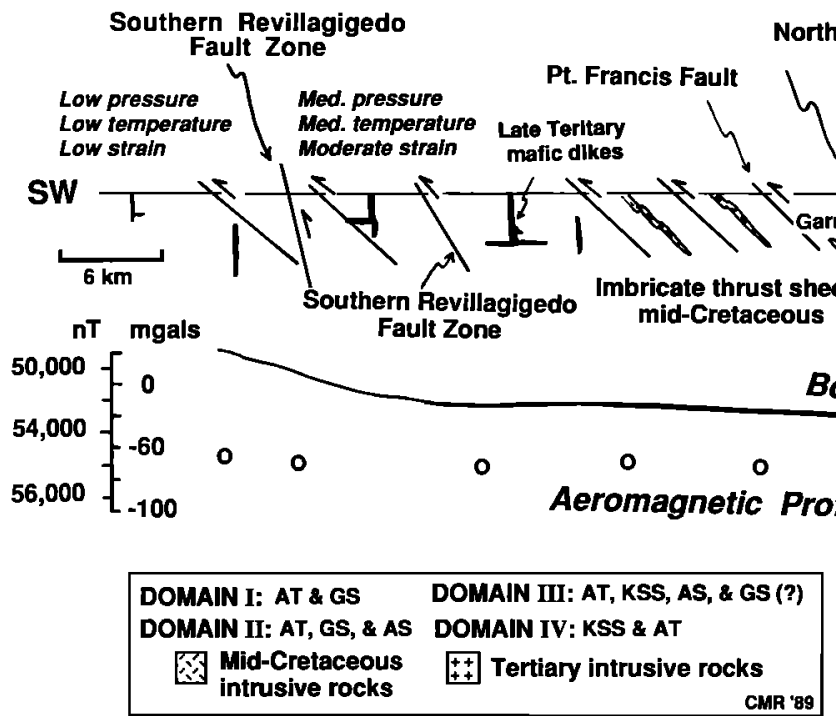

Domain III

Domain IV

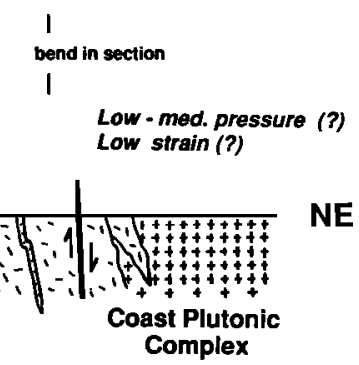

1 Fault Zone
Fevillagigedo

Med. pressure High temperature High strain

Fig. 13. Aeromagnetic and gravity profiles and geologic cross section across the western wall rocks of the Coast Plutonic Complex showing the major mid-Cretaceous structural domains. Abbreviations are AS, Alava sequence; AT, Alexander terrane; GS, Gravina sequence; and KSS, Kah Shakes sequence. Med. is medium. Domain IV is not discussed in this paper.

however, penecontemporaneous recrystallization overprints this fabric. There is a predominance of moderate west-dipping foliation surfaces which are axial planar to asymmetric eastverging folds. These east-verging fabrics have reoriented earlier mid-Cretaceous fabrics. Late Paleocene pegmatite dikes are highly deformed and are affected by these east- and westdipping structures (Figure 2) [Saleeby and Rubin, 1989]. Exposure of the gneiss complex may have resulted from eastvergent Paleocene deformation, when deep levels of the midCretaceous thrust system were transported upward along younger east-vergent structures. A swarm of Tertiary hornblende-bearing diabase dikes crosscuts all structures and fabrics. These dikes trend northeast (Figure 11c) and mark a regional change in the overall tectonic setting during Miocene time.

\section{DISCUSSION AND TECTONIC HISTORY}

Three major lithotectonic assemblages, the Alexander and Taku terranes and the Gravina sequence, are present along a northwest-trending belt on the western side of the Coast Plutonic Complex. The upper Paleozoic portion of the Alava sequence may represent the westernmost extent of the YukonTanana terrane, an assemblage of lower Palcozoic continental slope-and-rise deposits and dismembered fragments of a mid- to late Paleozoic arc system. The lower Mesozoic part of the Alava sequence has lithologic similarities to parts of the Stikine terrane. Structural basement is composite and consists of the Alexander and Taku (Alava and Kah Shakes sequences) terranes. The Alexander terrane forms depositional basement to the Gravina sequence; locally the epiclastic strata of the Gravina sequence lie unconformably over the upper Paleozoic and lower Mesozoic Alava sequence [Rubin and Saleeby, 1991c], thus forming an overlap between the two basement constituents (Alexander terrane and Alava sequence). These data suggest the Alexander terrane was adjacent to the western margin of North America prior to deposition of the Upper Jurassic to Lower Cretaceous Gravina sequence.

The record of sedimentation, magmatism, and deformation within the Gravina belt spans an interval of almost 50 m.y., from the Late Jurassic to the end of the Early Cretaceous. Beginning in the Late Jurassic, primitive arc-type (?) basaltic to basaltic andesite volcanic rocks of the Gravina sequence were deposited on basinal epiclastic strata that unconformably overlie Triassic and older portions of the Alexander terrane (Insular composite terrane) and the upper Paleozoic and lower Mesozoic Alava sequence (e.g., Yukon-Tanana and Stikine terranes and Intermontane composite terrane [Rubin and Saleeby, 1991a]). Thus the Insular and Intermontane composite terranes were adjacent during construction of the overlying Late Jurassic to Early Cretaceous Gravina arc. Coarse-grained epiclastic and volcanic basinal strata of the Gravina sequence overlie the older volcanic rocks. Provenance of the clastic rocks indicates uplift erosion of the older plutonic arc edifice, perhaps within an extensional tectonic setting [Rubin and Saleeby, 1991c]. Following deposition of the Gravina sequence, zoned mafic and ultramafic complexes were emplaced into the Alexander terrane on Duke and Annette Islands (e.g., the Duke Island ultramafic complex) and the Gravina sequence (e.g., the Union Bay ultramafic complex) and are present as numerous smaller bodies that intrude adjacent terranes. These enigmatic bodies form a linear belt parallel to the Gravina sequence along the eastern edge of the Alexander terrane and may have been emplaced during the onset of mid-Cretaceous deformation, possibly in an extensional setting. After deposition of the Gravina sequence and after the emplacement of the zoned ultramafic complexes, significant mid-Cretaceous deformation and metamorphism affected these rocks and their basement components.

Mid-Cretaceous deformation is recorded on Cleveland Peninsula, Revillagigedo Island, and the eastern portions of Annette, Gravina, and adjacent islands. Asymmetric west to southwest-vergent folds formed during thrust faulting. Thrust 
sheets of the lower Paleozoic Kah Shakes sequence overlie the Alexander terrane and Gravina and Alava sequence nappes; however, locally on Portland Peninsula, the Kah Shakes sequence lies structurally below deformed Alexander terrane [Saleeby and Rubin, 1990b]. Complex thrust geometries and out of sequence thrust faults may have resulted from the reactivation of different primary basement components. Deformation is recorded on Cleveland Peninsula and Revillagigedo and adjacent islands by (1) west- to southwestvergent thrust faulting, (2) pervasive metamorphism, ranging from lower greenschist to amphibolite facies mineral assemblages, (3) emplacement of calc-alkaline sills, dikes, and plutons, (4) high-angle reverse faulting, and (5) uplift that records at least $14 \mathrm{~km}$ of vertical transport by Late Cretaceous time. Available age constraints from Revillagigedo and adjacent islands indicate that this deformational event began in the Albian $(\sim 113 \mathrm{Ma})$, the age of the youngest strata involved in thrust faulting, and must have ceased by $\sim 74 \mathrm{Ma}$, based on biotite K-Ar cooling ages [Smith and Diggles, 1981] from mid-Cretaceous plutons. Asymmetric west- to southwestvergent folds formed during this faulting. The presence of thrust sheets composed of crystalline basement may imply a zone of decoupling within middle levels of the continental crust during the mid-Cretaceous. The extent of southwestdirected thrusting of the Yukon-Tanana terrane over the Gravina sequence and its composite basement is difficult to assess; however, it is possible that a subhorizontal décollement separating the Yukon-Tanana and Alexander terrane extends beneath northern British Columbia and southern Yukon Territory [Rubin and Saleeby, 1991b].

The emplacement of mid-Cretaceous sills, dikes, and elongate plutons was broadly coeval with deformation. The details of the relation between deformation and pluton emplacement, however, are complicated [Crawford and Crawford, 1991]. These calc-alkaline intrusive rocks formed in response to plate convergence along the western margin of the Alexander terrane and at middle crustal levels of a midCretaceous continent-margin arc [Barker and Arth, 1984]. Mid-Cretaceous ages reported here, together with older U-Pb dates from the Ketchikan area [C. M. Rubin, unpublished data, 1988] indicate an overall progression of older to younger midCretaceous igneous ages from the southwest to northeast (Figure 14). This trend may reflect a northeast migration of the mid-Cretaceous arc between 100 and $90 \mathrm{Ma}$. Steeply dipping reverse faults became active during the late stages of thrust faulting. Vertical motion on these faults resulted in the juxtaposition of differing crustal levels across the thrust belt and was perhaps responsible for the initial uplift of the deeper levels of the arc by the latest Cretaceous, reflected by an average uplift rate of $\sim 0.9 \mathrm{~mm} / \mathrm{yr}$ [Rubin and Saleeby, 1991b]. K-Ar cooling ages indicate that the western side of the thrust belt cooled below the biotite closure temperature by $74 \mathrm{Ma}$ (Figure 14) [Smith and Diggles, 1981]. Highly deformed late Paleocene to early Eocene tonalitic and granodioritic intrusives are present on eastem Revillagigedo Island and western Portland Peninsula, and belong to a discontinuous belt of sills and elongate plutons that were intruded into overthickened crust along the westem flank of the Coast Plutonic Complex. Rapid uplift accompanied the emplacement of these plutons [Hollister, 1982; Crawford et al., 1987] and may record the gravitational collapse of the midCretaceous thrust belt, although a contractional setting has also been proposed. An abrupt step in the K-Ar cooling ages indicates that the eastern part of the thrust belt passed through the biotite closure temperature by $\sim 58 \mathrm{Ma}$. Uplift in the region was probably accommodated by east-side-up faults. Alternatively, it is possible that the older K-Ar cooling ages may reflect cooling due to underthrusting of cold material

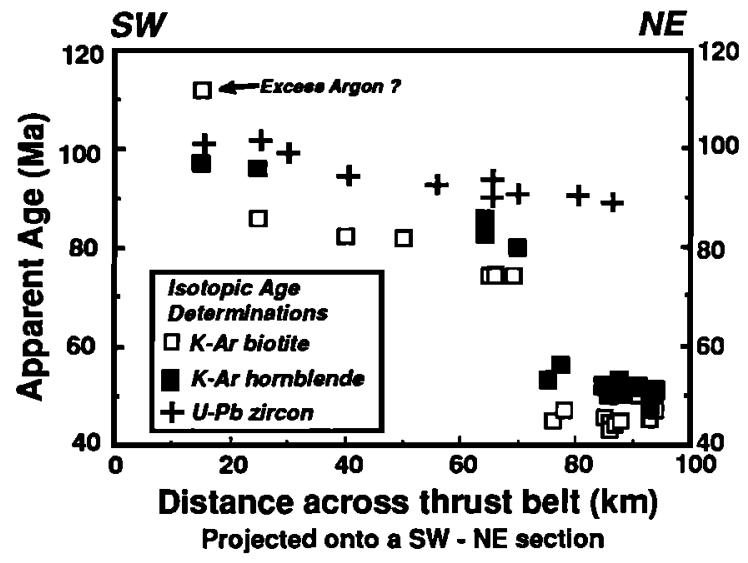

Fig. 14. U-Pb zircon ages and $\mathrm{K}-\mathrm{Ar}$ cooling ages for $100-90$ Ma plutons in the Ketchikan area. U-Pb ages are after Arth et al. [1988] and Rubin and Saleeby (this paper and unpublished data). K-Ar data are from Smith and Diggles [1981].

beneath the arc coeval during the eastward migration of magmatism. In this view, the eastward change of $\mathrm{K}-\mathrm{Ar}$ biotite ages may reflect not regional uplift but flattening of the subducting slab and the resultant underflow of a relatively cold subducting plate (for example, see Dumitru [1990]). Presentday thermal gradients in much of the region are low [Yorath et al., 1985], consistent with a forearc setting for the western part of the Coast Plutonic Complex.

Limited gravity and aeromagnetic data along the trend of the thrust belt help define the present-day deeper crustal structure [Barnes, 1972a, b; 1977; United States Geological Survey (USGS), 1977]. The dramatic decrease in Bouguer gravity anomaly values, from about $+10 \mathrm{mGal}$ in the nondeformed portions of the Alexander terrane to about $-115 \mathrm{mGal}$ in the interior of the thrust belt, along the western edge of the Coast Plutonic Complex (Figure 13), may reflect a thickened crust and associated large volumes of granitic material. A strong Bouguer gravity gradient coincides with the thicker parts of the thrust wedge and the presence of mid-Cretaceous and younger intrusive rocks. A steep magnetic field gradient from low magnetic strata of nondeformed Alexander terrane on the west to highly magnetic eastern portions of the thrust belt and the westem edge of the Coast Plutonic Complex [USGS, 1977] mirrors the Bouguer gravity gradient. Bouguer gravity data [Barnes, 1977] suggest a crustal thickness of $\sim 25-30 \mathrm{~km}$ beneath the southeast Alaska archipelago (i.e., Alexander terrane and Gravina sequence). Crustal thickness beneath the Coast Plutonic Complex may be as thick as $40 \mathrm{~km}$; however, gravity data alone cannot resolve Moho depths. The presence of thinned lithosphere in which midcrustal levels are exposed on the Earth's surface poses fundamental questions on the character and nature of the lithospheric structure beneath the Coast Plutonic Complex. Tertiary and younger (?) crustal thinning may have been accomplished by extension; however, the role of extension is presently difficult to assess. A northeast-trending swarm of late Tertiary mafic dikes cuts all Cretaceous and early Tertiary structural elements and records northwest-southeast extension. This dike swarm may reflect regional extension associated with the opening of Hecate Strait during the late Tertiary. The modern structural setting is dominated by dextral strike-slip motion on the Queen Charlotte fault system.

The mid-Cretaceous southeast Alaska orogen was characterized by thrust faulting, metamorphism, and the emplacement of arc-related tonalitic and granodioritic plutons. 
Igneous activity and deformation were broadly coeval, suggesting an intra-arc setting. Mid-Cretaceous rocks exposed at the surface today were formed in middle crustal levels of a continent-margin arc and were involved in tectonic reworking of an older crustal boundary between the Alexander terrane and the western margin of North America. Most penetrative deformation occurred where structural reactivation of differing basement components, such as the Alexander terrane and the Kah Shakes sequence, resulted in complex fault geometries. Emplacement of the early Tertiary tonalitic to granitic plutons followed mid-Cretaceous crustal shortening and uplift. These data clearly indicate that deformation and magmatism were integral parts of the ongoing tectonic evolution of a convergent continental margin and did not result from a shortlived collisional event. Because crustal shortening was broadly contemporaneous with arc magmatism, the subduction of oceanic lithosphere played a major role in crustal shortening in a noncollisional setting. During the evolution of the orogen, mid-Cretaceous magmatic processes thermally weakened and allowed compressional failure of the overriding continental plate.
Acknowledgments. Parts of this research were supported by National Science Foundation grants EAR 86-05386 and EAR 88-034834 (to Saleeby). Additional support (to Rubin) was provided by a Geological Society of America Penrose grant, a Sigma-Xi grant-in-aid, by the U. S. Geological Survey, Alaska Branch, and by the U.S. Forest Service, Ketchikan Ranger District. Rick Allmendinger graciously provided the stereonet programs. We thank Fred Barker, Henry Berg, Dave Brew, Darrel Cowan, Weecha Crawford, John Garver, George Gehrels, Linc Hollister, Bill McClelland, Meghan Miller, Jim Monger, George Plafker, and Margi Rusmore for helpful discussions on northwest Cordilleran stratigraphy and tectonics. Jim Wright provided encouragement and advice on $\mathrm{U}-\mathrm{Pb}$ zircon leaching techniques. Jeff Marshall assisted in mapping part of the area during the summer of 1987; Mark Fahnestock and Jon Nourse provided able field assistance during the summer of 1986. Field discussion with Bill McClelland and Meghan Miller are appreciated. A review by Weecha Crawford significantly improved the clarity of an earlier version of this paper. Hank Berg and Margi Rusmore thoroughly reviewed the manuscript.

\section{REFERENCES}

Arth, J. G., F. Barker, and T. W. Stem, Coast Batholith and Taku plutons near Ketchikan, Alaska: Petrography, geochronology, geochemistry, and isotopic character, Am. J. Sci., 288-A, 461-489, 1988.

Barker, F., and J. G. Arth. Preliminary results, Central Gneiss Complex of the Coast Plutonic batholith, southeastem Alaska: the roots of a high-K, calc-alkaline arc?, Phys. Earth Planet. Inter., 35, 191-189, 1984 .

Bames, D. F., Simple Bouguer gravity anomaly map of Ketchikan 1:250,000 quadrangle, southeastern Alaska, showing station locations, anomaly values, and generalized 10 milligal contours, U.S. Geol. Surv. Open File Map, 1972a.

Barnes, D. F., Simple Bouguer gravity anomaly map of Craig 1:250,000 quadrangle. southeastern Alaska, showing station locations, anomaly values, and generalized 10 milligal contours, U.S. Geol. Surv. Open File Map, $1972 b$.

Bames, D. F., Interpretation of the available gravity, in Mineral Resources of the Tracy Am-Fords Terror wildemess study area and vicinity, edited by D. A. Brew, A. L. Kimball, D. Grybeck, and J. C. Still,. Geol. Surv. Open File Rep., 77-649, 300 pp, 1977.

Berg, H. C., Geologic map of Annette Island, Alaska, scale 1:63,000, U.S. Geol. Surv. Misc. Geol. Invest. Map, I-684, 8p., 1972.

Berg, H. C., Geology of Gravina Island, Alaska, U.S. Geol. Surv. Bull. 1373, 41 pp., 1973.

Berg, H. C., and E. L., Cruz, Map showing locations of fossil collections and related samples in the Ketchikan area and Prince Rupert quadrangles, southeastem Alaska, scale $1: 250,000$, U.S. Geol. Surv. Open File Rep. $82-1088,27$ p., 1982.

Berg, H.C., D. L. Jones, and D. H. Richter Gravina-Nutzotin belt: Tectonic significance of an upper Mesozoic sedimentary and volcanic sequence in southem and southeastem Alaska, U.S. Geol. Surv. Prof. Pap. 800-D, D1- D24, 1972

Berg, H. C., R. L. Elliott, and R. D. Koch, Geologic map of the Ketchikan and Prince Rupert quadrangles, Alaska, scale 1:250,000 U.S. Geol. Surv. Misc. Invest. Ser., Map, 1 1807, scale 1:250,000, 1988.

Brew, D. A., and S. M. Karl, Reexamination of the contacts and other features of the Gravina belt, southeastem Alaska, in Geologic studies in Alaska by the U.S. Geological. Survey during 1987, edited by J. P. Galloway, and T. D. Hamilton, U.S. Geol. Surv. Circ., 1016 143-146, 1987

Brew, D. A., and R. P. Morrell, Intrusive rocks and plutonic belts in southeastem Alaska, U.S.A., Circum-Pacific Plutonic terranes, edited by J.A. Roddick, Geol. Soc. Am. Mem., 159, 171-194, 1983

Chen, J. H., and G. J. Wasserburg, Isotopic determination of uranium in picomole and subpicomole quantities, Anal. Chem., 53, 2060-2067, 1981.

Cook, R. D., M. L. Crawford, G. I. Omar, and W. A. Crawford, Magmatism and deformation, southern Revillagigedo Island, SE Alaska, Geol. Soc. Am. Bull., 103, 829-841, 1991.

Crawford, M. L, and W. A. Crawford, Magma emplacement in a convergent tectonic orogen, southem Revillagigedo Island, southeastem Alaska, Can. J. Earth Sci., in press, 1991.

Crawford, M. L., L. S. Hollister, and G. J. Woodsworth, Crustal deformation and regional metamorphism across a terrane boundary. Coast Plutonic Complex, British Columbia, Tectonics, 6, 343-361, 1987.

Dumitru, T. A., Subnormal Cenozoic geothermal gradients in the extinct Sierra Nevada arc: Consequences of laramide and post-laramide shallow-angle subduction, J. Geophys. Res. 95, 4925-4941, 1990.

Eberlein, G. D., M. Churkin, Jr., C. Carter, H. C. Berg, and A.T. Ovenshine, Geology of the Craig quadrangle, Alaska, scale 1:250,000,
U.S. Geol. Surv. Open File Rep., 83-91, 53p, U.S. 1983 .

Gehrels, G. E., and W. C. McClelland, Outline of the Taku terrane and Gravina belt in the Cape Fanshaw-Windham Bay region of central southeastem Alaska Geol Soc Am Abstr. Programs, 20, 163, 1988.

Gehrels, G. E., and J. B. Saleeby, Geology of Prince of Wales Island, southeastem Alaska, Geol. Soc. Am. Bull., 98, 123-137, 1987.

Gehrels, G. E., J.B. Saleeby, and H. C. Berg, Geology of Annette, Gravina, and Duk Islands, southeastem Alaska, Can. J. Earth Sci., 24, 866-881, 1987.

Gehrels, G. E., W. C. McClelland, S. D. Samso P. J. Patchett, and J. L. Jackson, Ancien continental margin assemblage in the northem Coast Mountains, southeast Alaska and northwest Canada, Geology. 18, 208-211. 1990.

Gehrels, G. E., W. C. McClelland, S. D. Samson, P. J. Patchett, and J. L. Jackson, U-Pb geochronology of detrital zircons from the Yukon crystalline terrane in the northem Coast Mountains batholith, southeastern Alaska, Can. J. Earth Sci., 28, 899-911, 1991.

Gehrels, G. E. W. C. McClelland, S. D. Samson, P. J. Patchett, and M. J. Orchard, Geology of the westem flank of the Coast Mountains between Cape Fanshaw and Taku Inlet, southeastern Alaska, Tectonics, in press 1992.

Hammarstrom, J. M., and E-A. Zen, Aluminum in hornblende: An empirical igneous geobarometer, Am. Mineral, 71, 1297-1313, 1986 .

Herreid, G., T. K. Bundtzen, and D. L. Tumer, Geology and geochemistry of the Craig A-2 quadrangle and vicinity, Prince of Wales Island, southeastem Alaska, Geol. Rep. Alasko Div. Geol. Geophys. Surv., 48, 49p., 1978.

Holdaway, M. J., Stability of andalusite and the aluminum silicate phase diagram, Am. $J$. Sci., $271,97-131,1971$

Hollister, L. S., Metamorphic evidence for rapid ( $2 \mathrm{~mm} / \mathrm{yr}$ ) uplift of a portion of the Central Gneiss Complex, Coast Mountains, Brutsh Columbia, Can. Mineral., 20, 319-332, 1982.

Cllism Stowell, and V. B. Sisson, Confimation of the Stowell, and V. B. Sisson, Confimation of the pressure solidification of calc-alkaline plutons, Am. Min., 72, 231-239, 1987.

Irvine, T. N., The Duke Island ultramafic complex, southeastem Alaska, in Uluramafic and Related Rocks, edited by P. J. Wyllie, pp. 84-97, John Wiley, New York, 1967.

Irvine, T. N., Petrology of the Duke Island ultramafic complex, southeastern Alaska, Mem. Geol. Soc. Am. 138, 1974.

Jaffey, A. H., K. F. Flynn, L. E. Glendenin, W. C. Bentley, and A. M. Essling, Precision measurement of half-lives and specific activities of $235 \mathrm{U}$ and ${ }^{238} \mathrm{U}$, Phys. Rev. C, 4 , 1889-1906, 1971

Johnson, M. C., and M. J. Rutherford, Experimental calibration of aluminium-inhomblende geobarometer with application to Long Valley aldera (Califomia) volcanic rocks, Geology, 17, 837-841, 1989.

Kamb, W. B., Theory of preferred orientation developed by crystallization under stress, $J$. Geol., 67, 153-170, 1959.

Krogh, T. E., A low-contamination method for hydrothermal decomposition of zircon and extraction of $\mathrm{U}$ and $\mathrm{Pb}$ for isotopic age determinations, Geochim. Cosomochim. Acta, 37, 485-494. 1973. 
Lanphere, M. A., and G. D. Ekerlein, Potassiumargon ages of magnetite-bearing ultramafic complexes in southeastem Alaska, Spec. Pap. Geol. Soc. Am. 87, 94, 1966

Magaritz, M., and H. P. Taylor, Jr., Oxygen $18 /$ oxygen 16 and D/H studies of plutonic granitic and metamorphic rocks across the Cordilleran batholiths of southem British Columbia, J. Geophys Res., 91, 2193-2217, 1986.

Mattinson, J. M., U-Pb ages of zircon: a basic examination of error propagation, Chem. Geol., 66, 151-162, 1987

McClelland, W. C., and G. E. Gehrels, Geology of the Duncan Canal shear zone: Evidence for Early to Middle Jurassic deformation of the Alexander terrane, southeastem Alaska, Geol. Soc. Am. Bull., 102, 1378-1392, 1990.

McClelland, W. C., G. E. Gehrels, S. D. Samson, and P. J. Patchett, Structural and geochronologic relations along the westem flank of the Coast Mountains batholith: Stikine River to Cape Fanshaw, central southeastem Alaska, J. Struct. Geol,, in press 199

McClelland, W. C., G. E. Gehrels, S. D. Samson, and P. J. Patchett, Protolith relations of the Gravina belt and Yukon-Tanana terrane in central southeastem Alaska, J. Geol., 1992b.

Rubin, C. M., and J. B. Saleeby, The inner boundary zone of the Alexander terrane in southem SE Alaska, A newly discovered thrust belt, Geol. Soc. Am. Abstr. Programs, 19. 455, 1987.

Rubin, C. M., and J. B. Saleeby, Tectonic framework of the Upper Paleozoic and Lower Mesozoic Alava sequence: A revised view of the polygenitic Taku terrane in southem southeast Alaska, Can. J. Earth Sci., 28, 881893, 1991a.

Rubin, C. M. and J. B. Saleeby, Thrust tectonics and intracontinental shortening in southeas Alaska and western British Columbia, in Thrust Tectonics, edited by by K. McCLay, Unwin Hyman, London, in press. 1991b.

Rubin, C. M., and J. B. Saleeby. The Gravina Sequence - Remnants of a mid-Mesozoi oceanic arc in southem southeast Alaska, $J$. Geophys. Res., 96, 14551-14568, 1991c.

Rubin, C. M., J. B. Saleeby, D. S. Cowan, M. T. Brandon, and M. F. McGroder, Regionally extensive mid-Cretaceous west-vergent thrust system in the northwestern Cordillera:
Implications for continent-margin tectonism Geology, 18, 276-280, 1990a.

Rubin, C. M. M. M. Miller and G. E. Smith Tectonic development of Cordilleran midPaleozoic volcanoplutonic complexes Evidence for convergent margin tectonism, in Paleozoic and early Mesozoic paleogeographic relations; Sierra Nevada, Klamath Mountains. and related rocks, edited by D. S. Harwood and M. M. Miller, Spec. Pap. Geol. Soc. Am., 225, 1-16, $1990 \mathrm{~b}$.

Saleeby, J. B., The inner boundary zone of the Alexander terrane in southem SE Alaska: Part II southem Revillagigedo Island (RI) to Cape Fox (CF), Geol. Soc. Am. Abstr. Programs, 19. $828,1987$.

Saleeby, J. B., and C. M., Rubin, The westem margin of the Coast Plutonic Complex (CPC) in southernmost SE Alaska, Geol. Soc. Am. Abstr. Programs, 21, 139, 1989.

Saleeby, J. B., and C. M., Rubin, The East Behm Canal Gneiss Complex (southem southeast Alaska) and some insights into basement tectonics along the Insular suture belt, Geol. Assoc. Can. Abst. Programs, 15, A116, 1990a.

Saleeby, J. B., and C. M. Rubin, Tectonic intercalation of crystalline nappes and basinal overlap relations in southern SE Alaska: Implications for the initial stages of Insular superterrane accretion, Eos Trans. AGU, 71, $1591,1990 \mathrm{~b}$.

Saleeby, J. B., G. E. Gehrels, G. D. Eberlein, and H. C. Berg, Progress in lead/uranium zircon studies of lower Paleozoic rocks of the southem Alexander terrane, U.S. Geol. Surv. southem Alexander terrane,
Circ., 868, 110-113, 1984.

Silberling, N. J., Wardlaw, B. R., and H. C. Berg, New paleontologic age determinations form the Taku terrane, Ketchikan area, southeastem Alaska, U.S. Geol. Surv. Circ., 844, 117-119, 1982.

Smith, J. G., and M. F. Diggles, Potassium-argon determinations in the Ketchikan and Prince Rupert quadrangles, southeastem Alaska, U.S Geol. Surv. Open File Rep., 78-73N, 1-6, 1981 .

Sutter, J. F., and M. L. Crawford, Timing of metamorphism and uplift in the vicinity of Prince Ruper, British Columbia, Geol. Soc. Am. Abstr. Programs, 17, 411, 1985.

Taylor, H. P., Jr., The zoned ultramafic complexes of southeastem Alaska, in Ultramafic and Related Rocks, edited by P. J. Wyllie, pp. 209-230, John Wiley, New York, 1967.

Tera, F., and G. S. Wasserburg, U-Th-Pb systematics in three Apollo 14 basalts and the problems of the initial $\mathrm{Pb}$ in lunar rocks, Earth Planet. Sci. Lett., 14, 281-304, 1972

Tumer, F. J., Metamorphic Petrology, 2nd ed., 524 pp., publisher, New York, 1981.

United States Geological Survey (USGS), Aeromagnetic map of the Ketchikan, Prince Rupert, and northeastem Craig quadrangles, Alaska, scale $1: 250,000, U . S$. Geol. Surv. Open File Rep. Map 77-359, 1977.

Wheeler, J. O., and P. McFeely, Tectonic assemblage map of the Canadian Cordillera, Geol. Surv. Can. Open File Rep. 1565, 1987.

Yorath, C.J., G. J. Woodsworth, R. P Riddihough, R.G. Currie, R. D. Hyndman, G. C Rogers, D. A. Seemann, and A. D. Collins, Centennial Continent/Ocean Transect \# 8, Intermontane Belt (Skeena Mountains) to Intermontane Belt (Skeena Mountains) to Soc. America. Centennial Continent/Ocean Transect Ser., 8,7 pp. Geological Society of America, Boulder, Colo., 1985.

York, D., Least-squares fitting of a straight line with correlated errors, Earth Planet. Sci. Lett., 5, 320-324, 1969.

Zen, E-A., Implications of magmatic epidotebearing plutons on crustal evolution in the accreted terranes of northwestern North America, Geology, 12, 266-269, 1985.

Zen, E-A., Tectonic significance of high-pressure plutonic rocks in the westems (sic) cordilleran of North America, in Metamorphism and Crustal Evolution of the Western United States, Rubey Volume 7, edited by W. G. Emst, PP. 41-68, Prentice-Hall, Englewood Cliffs, N.J. 1988 .

Zen E-A., and J. M. Hammarstrom, Magmatic epidote and its petrologic significance. Geology, 12, 515-528, 1984.

C. M. Rubin, Department of Geology, Central Washington Univerity, Ellensburg, WA 98926. J. B. Saleeby, 170-25 Geology, Californi Institute of Technology, Pasadena, CA 91125.

(Received February 21, 1991;

rovised August 5, 1991;

accepted August 8, 1991.) 